\title{
Brytyjskie wyroby ceramiczne na gdańskim rynku produktów w XVIII i XIX wieku
}

\section{British ceramics in Gdańsk local market in $18^{\text {th }}$ and $19^{\text {th }}$ century}

Badania archeologiczne prowadzone na obszarach miejskich dostarczają licznych źródeł ruchomych, pozwalających poznać zjawiska społeczne i ekonomiczne minionych stuleci. Wciąż nie docenianą przez archeologów kategorią przedmiotów są te z XVIII i XIX wieku.

Ujęta w pracy problematyka dotyczy brytyjskich (angielskich i szkockich) wyrobów ceramicznych z okresu od XVIII do XIX wieku, pozyskanych w wyniku badań archeologicznych w Gdańsku. Wśród nich wyróżniono naczynia ceramiczne, fajki i ceramikę budowlaną. Dla zobrazowania podjętego tematu zaprezentowano wybrane materiały ze stanowisk archeologicznych zlokalizowanych w różnych częściach Gdańska: w obrębie Starego Miasta, Starego Przedmieścia, Południowej Wyspy Spichrzów i Szafarni (ryc. 1). Ze względu na bogatą bazę źródłową i złożoność poruszanych zagadnień, w niniejszym artykule problematyka badawcza została przedstawiona w sposób przede wszystkim wprowadzający. Wstępnie scharakteryzowano poszczególne kategorie wyrobów, określono ich chronologię oraz potencjał informacyjny wynikający z obecności na gdańskim rynku produktów.

Studia nad prezentowanym zagadnieniem wynikają z dużej liczby tej kategorii źródeł pozyskiwanych podczas badań archeologicznych na obszarach miejskich oraz wciąż niewielkiej liczby opracowań tej tematyki odnoszącej się do obszaru Polski.

Naczynia ceramiczne wytwarzane w Anglii do tej pory w polskiej literaturze nie stanowiły tematu odrębnych opracowań czy studiów podjętych z perspektywy archeologicznej. Ich szerszą charakterystykę ujęto w monografii angielskiego wraku „General Carleton of Whitby” (Dąbal 2008). Nieliczne informacje prezentowane są w pracach dotyczących wyników badań poszczególnych stanowisk 


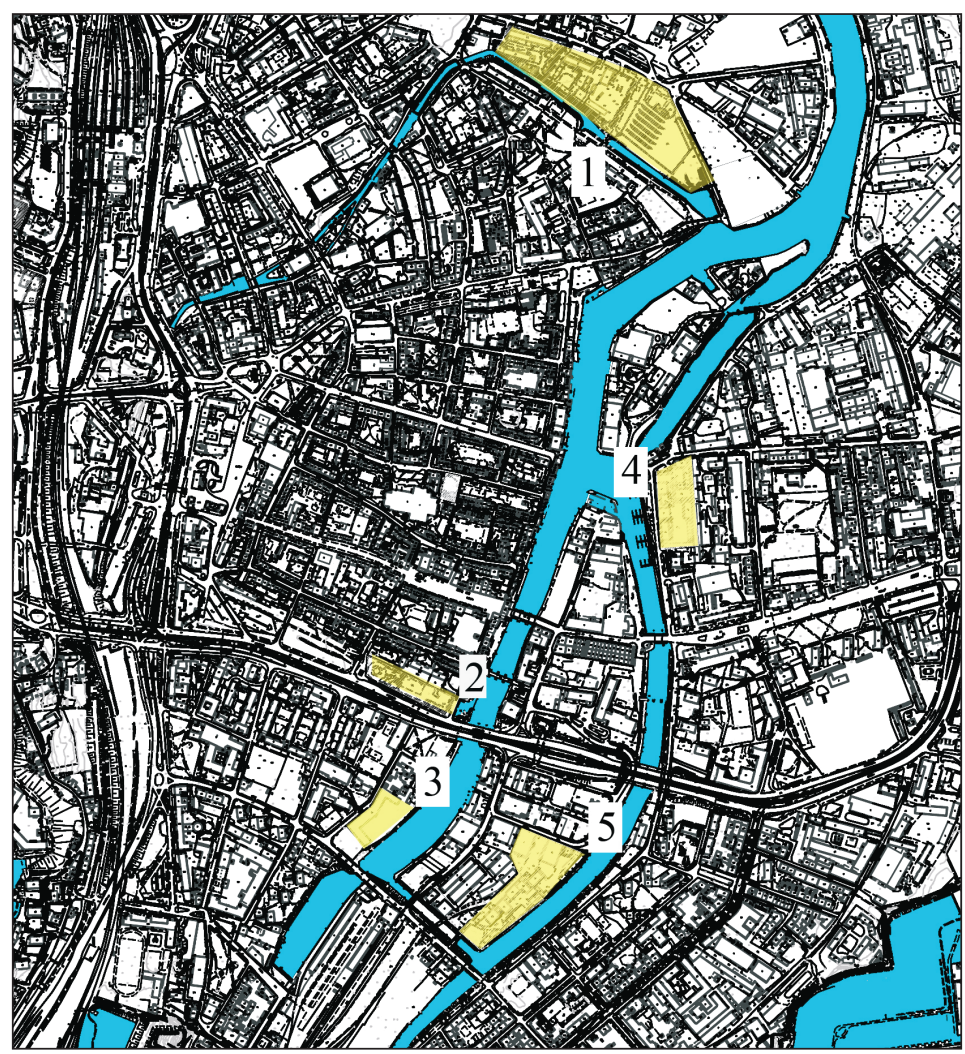

Ryc. 1. Gdańsk - lokalizacja stanowisk: 1 - ul. Wałowa 56;2 - ul. Podwale Przedmiejskie 519/17; 3 - ul. Lastadia 34-46; 4 - ul. Szafarnia 6, 8a, 8b, 9/Angielska Grobla 1; 5 - ul. Jaglana 3/5/; 6 - ul. Toruńska 10 (oprac. J. Dąbal)

Fig. 1. Gdańsk - site locations: 1 - 56 Wałowa st.; 2 - 519/17 Podwale Przedmiejskie st.; 3-34-46 Lastadia st.; 4-6, 8a, 8b, 9 Szafarnia st./1 Angielska Grobla st.; 5 -3/5 Jaglana st.; 6 - 10 Toruńska st. (elab. by J. Dąbal)

(Oniszczuk-Rakowska 2002, s. 46). Nieco szerzej wyroby te analizowano z perspektywy historyków sztuki (np. Kilarska, Litwin 1985; Szelegejd 2007, s. 70-73).

Angielskie i szkockie fajki z terenu Polski są jedynie wzmiankowane w artykułach poświęconych tej problematyce. Wśród opracowań dotyczących materiałów z Gdańska dwa zawierają ogólne informacje dotyczące tych źródeł (Mikłaszewicz 1993; Dyba 2009). Niejednokrotnie w polskich publikacjach archeologicznych argumenty przemawiające za poprawnością identyfikacji wytwórni fajek nie są dostatecznie przytaczane. Na tym tle wyroby brytyjskie wymagają szczególnej uwagi badawczej ze względu na liczne ich naśladownictwa, w tym szwedzkie i pruskie. Bezsporna identyfikacja ośrodka lub wytwórcy w odniesieniu do wyrobów brytyjskich jest niekiedy trudna do wskazania nawet dla badaczy angielskich 
czy szwedzkich. W niniejszej pracy podjęto próbę przybliżenia tej problematyki w kontekście egzemplarzy z badań archeologicznych w Gdańsku.

Badania nad nowożytną ceramiką budowlaną z wyłączeniem kafli nie stanowią rozwiniętego obszaru zainteresowań studiów archeologicznych. W ostatnich latach prace dotyczące cegieł i detali architektonicznych zostały wzbogacone o nieliczne publikacje, głównie jednak odnoszące się do wyrobów gotyckich (Cegła $w$ architekturze 2002; Skowrońska 2011). Z tej perspektywy badawczej przedstawione w niniejszym artykule materiały są również nową kategorią źródeł, wciąż jednak wymagającą dalszych studiów.

Przedstawione w artykule naczynia ceramiczne i fajki pochodzą z badań wykopaliskowych przy ulicach: Lastadia ${ }^{1}$, Szafarnia/Angielska Grobla ${ }^{2}$ oraz Wałowa ${ }^{3}$, zaś ceramika budowlana ze stanowisk przy ulicach: Podwale Przedmiejskie i Jaglana. Analizowane materiały źródłowe (naczynia ceramiczne i fajki) pozyskano głównie $\mathrm{z}$ warstw budowlanych służących podnoszeniu terenu oraz $\mathrm{z}$ warstw zasypiskowych. Ceramika budowlana stanowiła pierwotny lub wtórny budulec murów odsłoniętych podczas badań wykopaliskowych lub części infrastruktury wodno-kanalizacyjnej, opracowanych podczas dokumentacji architektonicznej (Dąbal 2009; 2012). Liczne zespoły źródeł pozyskane z tych miejsc stanowią niezwykle bogatą bazę informacyjną ${ }^{4}$, stanowiącą podstawę dalszych studiów. których potencjał poddano próbie interpretacji w kontekście Gdańska.

\section{Naczynia ceramiczne}

Podstawowym problemem badawczym podczas analizy naczyń ceramicznych pozyskiwanych podczas badań wykopaliskowych w Gdańsku jest określenie skali ich występowania. Uzyskane wyniki zależą od przyjętej metodyki wynikającej z postawionych pytań badawczych, liczebności całego zespołu, chronologii czy charakteru całego stanowiska. Wskazane czynniki stanowią zmienne, w wyniku których utrudnione jest porównywanie zespołów w zakresie wykraczającym poza liczby fragmentów. Analizując jedynie liczbę ułamków naczyń pochodzących z obszaru Anglii, znalezionych na poszczególnych stanowiskach w Gdańsku,

${ }^{1}$ Badania przy ulicach: Jaglanej 3/5, Podwale Przedmiejskie, działka 519/17 oraz Lastadia 34-38 prowadzone były przez Muzeum Archeologiczne w Gdańsku; za udostępnienie materiałów serdecznie dziękuję Dyrektorowi Muzeum dr. Henrykowi Panerowi oraz kierownikom badań: mgr. Marcinowi Jagusiakowi i mgr Karolinie Kocińskiej.

2 Badania przy ulicach: Szafarnia 6, 8a, 8b, 9/Angielska Grobla 1 prowadzone były przez firmę „Antiqua”; za udostępnienie materiałów dziękuję dr. hab. Bogdanowi Bobowskiemu.

${ }^{3}$ Badania przy ulicy Wałowej 56 prowadzone były przez agencję „DART”; za udostępnienie materiałów dziękuję mgr. inż. Jackowi Gzowskiemu, dr. hab. Bogdanowi Bobowskiemu oraz kierownikowi badań mgr. Patrykowi Muntowskiemu.

${ }^{4}$ Z badań przy ulicy Wałowej pozyskano 87376 fragmentów naczyń ceramicznych, 6526 fragmentów fajek, przy ulicy Szafarnia/Angielska Grobla - 25957 fragmentów naczyń ceramicznych, przy ulicy Lastadia - 1170 fragmentów fajek; całość zbiorów została opracowana przez dr Joannę Dąbal. 
otrzymujemy bardzo mylny obraz określający ich udział procentowy w przedziale od 1 do $3 \%{ }^{5}$. Jednak dla określenia skali ich występowania w Gdańsku bardziej miarodajne wydają się analizy liczby tej kategorii wyrobów (całych naczyń w oparciu o minimalną liczbę form) w obrębie koherentnych jednostek stratygraficznych. Takie badania wykonane dla stanowisk przy ulicy Szafarnia/ /Angielska Grobla oraz ulicy Wałowej ${ }^{6}$ wykazały stopniowe zwiększanie się udziału naczyń angielskich, w jednostkach stratygraficznych datowanych od 3. ćwierci XVIII wieku do początków XIX wieku, do około 14\% ${ }^{7}$. W oparciu o te wyniki można wysunąć tezę, że największa liczba naczyń angielskich użytkowana była przez mieszkańców Gdańska we wspomnianym okresie. Warto również zwrócić uwagę, że występują one jedynie pojedynczo w horyzontach osadniczych związanych z 2. połową XIX wieku.

Wśród angielskich naczyń ceramicznych z Gdańska wyróżniono: kamionkowe białe i brązowe (white saltglazed stoneware, brown stoneware), fajanse delikatne (creamware, pearlware), cienkościenne czerwone (redware) i cienkościenne czarne (blackware $)^{8}$. W całym zbiorze wyrobów angielskich najliczniejszą grupę stanowią wyroby fajansowe (od 91 do 98\%), mniej licznie odnotowywano naczynia kamionkowe (od 2 do $5 \%$ ), pojedynczo zaś czerwone i czarne (do $2 \%$ ).

Większość naczyń z Gdańska pochodzi z wytwórni zlokalizowanych w hrabstwie Staffordshire, w dystrykcie Stoke on Trent, w mniejszym stopniu w badanym zbiorze reprezentowane są wyroby z Liverpoolu. Stoke on Trent powstało w wyniku unii (w 1910 roku) sześciu głównych ośrodków wytwórczości: Stoke upon Trent, Hanley, Burslem, Tunstall, Longton i Fenton (Lawley 2010). Cały obszar wraz z Borough of Newcastle under Lyme i Staffordshire Moorlands to North Satffordshire często określany jest mianem The Potteries (ryc. 2) (Lawley 2010, s. 7-8). Do największych manufaktur Liverpoolu i okolicznych wytwórni hrabstwa Maryside należały: Herculaneum Pottery i Filnt Potworks (Towner 1978, s. 171-176). Liczne angielskie badania archeologiczne obejmujące obszary manufaktur, a także dobrze zachowane źródła historyczne dotyczące działalności tych wytwórni w wielu sytuacjach pozwalają na dokładne datowania poszczególnych egzemplarzy znajdowanych także w Gdańsku. Wyroby angielskie w rodzimej (anglojęzycznej) literaturze posiadają swoje nazwy wskazujące na technologię ich

\footnotetext{
${ }^{5}$ Wyroby angielskie ze stanowiska przy ulicy Szafarnia/Angielska Grobla stanowią 3\%, natomiast ze stanowiska przy ulicy Wałowej niecały $1 \%$.

${ }^{6}$ Dokładnej analizie poddano wybrane jednostki stratygraficzne, przyporządkowane do XVIII i XIX-wiecznych horyzontów osadniczych.

${ }^{7}$ Przykładowo dla stanowiska przy ulicy Wałowej 56, jednostka nr 2503 (2. połowa XVIII wiekupoczątek XIX wieku) - 13\%, nr 5333 (3. ćwierć XVIII wieku) - 3\%, dla stanowiska przy ulicy Szafarnia/Angielska Grobla, jednostka nr 797 (2. połowa XVIII wieku-początek XIX wieku) - 14\%, nr 380 (3. ćwierć XVIII wieku) - 3\%, nr 1102 (4. ćwierć XVIII wieku) - 11\%.

${ }^{8} \mathrm{~W}$ celu przeprowadzenia poprawnej identyfikacji wszystkich kategorii wyrobów, określenia grup technologicznych każdorazowo będą wskazywane w języku polskim (ogólnym określeniem) i angielskim (nazwą właściwą dla konkretnej kategorii wyrobów).
} 
Ryc. 2. Staffordshire, Wielka Brytania. Piece wytwórni Row of Glost, rok 1887 (wg Lawley 2010)

Fig. 2. Staffordshire, Great Britain. Row of Glost Factory ovens, 1887 (after Lawley 2010)

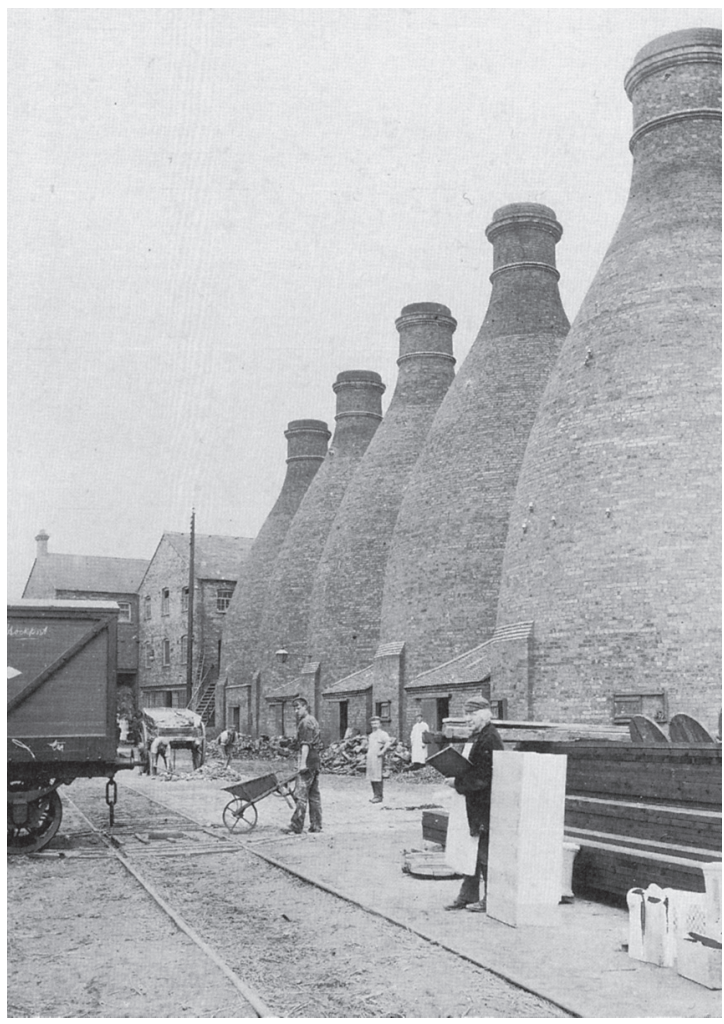

wykonywania. W języku polskim niekiedy brakuje dokładnych odpowiedników, dlatego do wszystkich grup zastosowano ogólne polskie pojęcia oraz oryginalne nazewnictwo.

Naczynia kamionkowe białe i brązowe (white saltglazed stoneware, brown saltglazed stoneware)

Inspiracją do powstania angielskich białych naczyń kamionkowych była chińska porcelana (Shaw 1829, s. 127). Początki wytwórczości tej kategorii wyrobów w Anglii sięgają końca XVII wieku. Z wprowadzeniem ich na rynek angielski i amerykański wiąże się postać Johna Dwighta działającego w Fulham (lata 1685-1695) (Edwards, Hampson 2005, s. 12-14). Rozwój i standaryzację produkcji wyrobów z białej kamionki wprowadził Josiah Wedgwood. Jednocześnie rozwinięcie działalności fabryki w ramach Wedgwood-Etruria od 1769 roku było jednym z ostatnich etapów ich popularności (do końca lat 90 . XVIII wieku) na ryku europejskim i amerykańskim (Draper 2001, s. 39; Edwards, Hampson 2005, s. 20).

$\mathrm{W}$ analizowanych materiałach opisywane wyroby reprezentowane są przez duże, płaskie talerze o krawędziach barokowych, w tym także zdobionych 
wypełniającym motywem w postaci ziaren wykonanym w wyniku odciskania w formie (ryc. 3). Ich chronologię, na podstawie dokładnie datowanych egzemplarzy z wytwórni Greatbatch'a, można określić na lata około 1770-1785 (Barker 1990, s. 78-79, 178-179). W grupie tej znalazły się również niezdobione i dekorowane spodki oraz czarki, a także pojedyncze egzemplarze naczyń do picia czekolady (ryc. 4, 5). Ornamenty na białych naczyniach kamionkowych z Gdańska wykonano techniką sgraffito w połączeniu z malowaniem błękitem kobaltowym (blue scrach); najczęściej są to motywy roślinne (ryc. 4: 2, 4). Tak zdobione egzemplarze datowane są na lata 1750-1770 (Thijssen 1993, s. 285; Edwards, Hampson 2005, s. 117, 226-227), zaś odnotowane w badanym zbiorze czarki i spodki bez zdobień - na lata 70.-80. XVIII wieku.

Brązowe naczynia kamionkowe stanowiły specjalność garncarzy z Londynu, Nottingham i Bristolu (Savage 1981, s. 48-53; Draper 1984, s. 33-35; Hume 2001, s. 168-180). Wśród analizowanych egzemplarzy z Gdańska odnotowano tylko jeden taki egzemplarz - kubek o cylindrycznym brzuścu zdobionym motywem reliefowym (engine turned) (ryc. 5). Analogiczne wyroby wytwarzane były na początku XIX wieku w Nottingham, Londynie i Bristolu (Edwards, Hampson 2005, s. 229, ryc. 192).

Naczynia fajansowe delikatne (creamware, pearlware)

Do produkcji tych naczyń stosowano białe, oczyszczone glinki, zmielone $\mathrm{z}$ kruszywem krzemiennym. Wyroby formowano na kole, odciskano w formie lub - od końca XVIII wieku - toczono mechanicznie (Barker 1990, s. 110, 119), następnie wypalano biskwit. W zależności od techniki zdobienia wykonywano je bezpośrednio na biskwicie lub po szkliwieniu. Dla tego rodzaju naczyń charakterystyczne jest szkliwo ołowiowo-boraksowe lub z kruszywa krzemiennego, po wypaleniu przybierające kolor kremowożółty (creamware) (Miller, Stone 1970, s. 42; Barker 1990, s. 132, 166; Kubalska-Sulkiewicz 2003, s. 108). Metody wytwarzania opisywanych naczyń zostały udoskonalone w końcu lat 50. XVIII wieku przez J. Wedgwooda (Jewitt 1865, s. 387-411; Miller, Stone 1970, s. 42; Towner 1978, s. 43-66).

Odmianę tej kategorii wyrobów stanowi tzw. pearlware, w przypadku której szkliwo jest ołowiowo-boraksowe z dodatkiem kobaltu, nadającego naczyniom delikatne, błękitne zabarwienia tła, naśladując chińską porcelanę (Sussman 1977, s. 105; Barker 1990, s. 166-167). Została ona wynaleziona i zastosowana przez J. Wedgwooda w 1779 roku (Sussman 1977, s. 105). Naczynia te, najczęściej malowane przykrawędnie, podszkliwnie oraz drukowane na niebiesko, były powszechne do lat 30. XIX wieku (Sussman 1977, s. 105).

Fajanse delikatne wytwarzane były głównie w Anglii. Do największych eksporterów należały wytwórnie w Stoke on Trent (Staffordshire), Liverpoolu i Leeds 


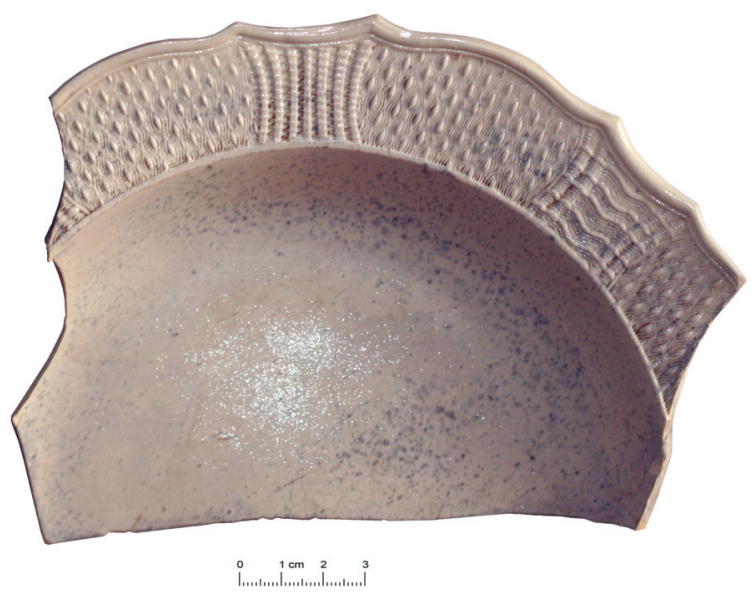

Ryc. 3. Gdańsk, ul. Wałowa 56. Fragment kamionkowego talerza (fot. J. Dąbal)

Fig. 3. Gdańsk, 56 Wałowa st. White saltglazed stoneware plate (photo by J. Dąbal)
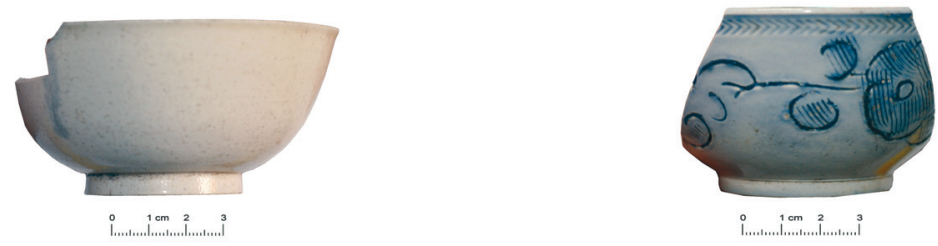

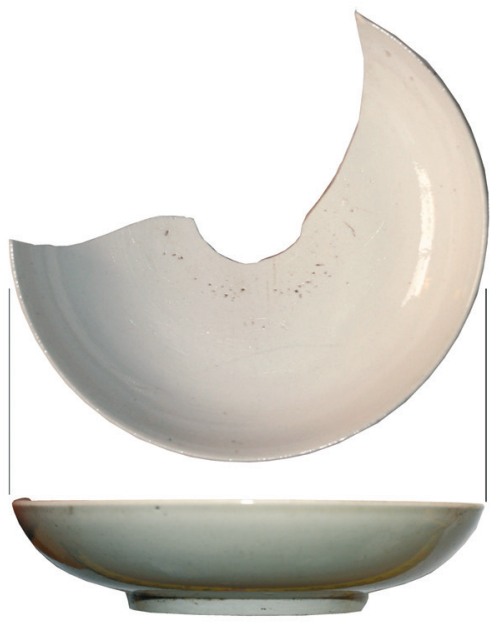

i. $\operatorname{lom}^{2}{ }^{2}{ }^{3}$

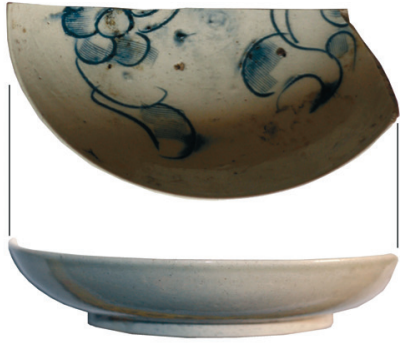

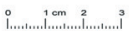

Ryc. 4. Gdańsk, ul. Wałowa 56. Fragmenty kamionkowych czarek i spodków (fot. J. Dąbal)

Fig. 4. Gdańsk, 56 Wałowa st. White saltglazed stoneware teacups and saucers (photo by J. Dąbal) 

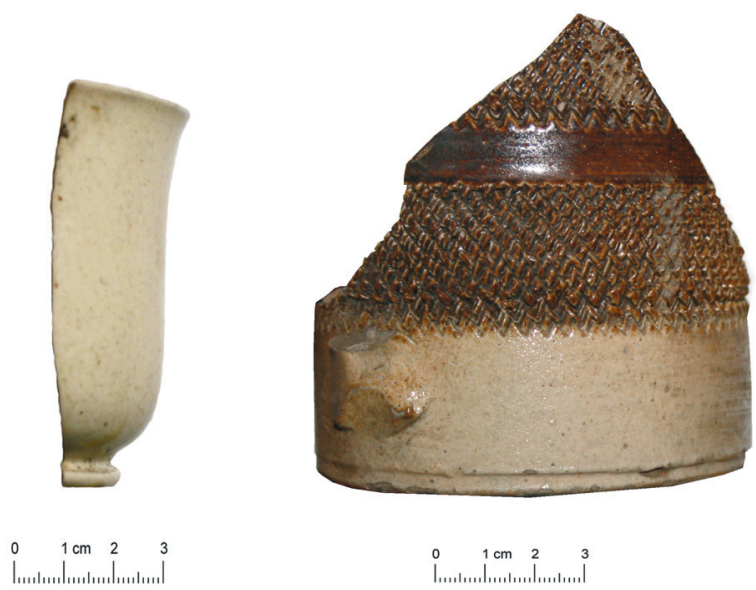

Ryc. 5. Gdańsk, ul. Wałowa 56. 1 - fragment kamionkowego naczynia do czekolady; 2 - fragment kubka (fot. J. Dąbal)

Fig. 5. Gdańsk, 56 Wałowa st. 1 - white saltglazed stoneware chocolate cup; 2 - brown stoneware mug (photo by J. Dąbal)

(Barker 1990, s. 166; Prentice 1994, s. 10-11; Hildyard 1999, s. 87). W latach 70. XVIII wieku technika ta została zastosowana w krajach Europy kontynentalnej; tak wykonane naczynia określano jako Faïence fine. Produkowano je między innymi we Francji (manufaktury Creil-Montereau czy Pont-aux-Choux), w Belgii (Anndene manufaktura Joseph Wouters'a) oraz Szwecji (Marieberg; jako Flint porslin) (Towner 1978, s. 181-187; Hildyard 1999, s. 87). Podczas procesu produkcji często asystowali wytwórcy ze Staffordshire (Hildyard 1999, s. 87).

Ze względu na technikę zdobienia wśród materiałów z Gdańska wyróżniono następujące grupy fajansów delikatnych: niedekorowane ${ }^{9}$ (creamware, pearlware), malowane podszkliwnie (creamware, pearlware), dekorowane podszkliwnie, wielobarwnie przy użyciu gąbki lub podobnego narzędzia (pearlware), marmoryzowane (creamware, pearlware), malowane przykrawędnie (creamware, pearlware), malowane naszkliwnie (creamware), zdobione techniką ,inkrustowany agat" (pearlware), oraz drukowane (creamware, pearlware $)^{10}$.

Najliczniejszą grupę stanowią wyroby bez dekoracji lub z plastyczną aplikacją, reprezentowane głównie przez głębokie i płytkie talerze, czarki, spodki oraz czajniki do herbaty i wazy. Wśród talerzy wyróżniono egzemplarze o krawędziach prostych (ascetycznych), barokowych oraz tzw. pierzastych (ryc. 6). Talerze z krawędziami drugiego i trzeciego rodzaju wytwarzano w latach 70.-90. XVIII wieku

\footnotetext{
${ }^{9} \mathrm{~W}$ tym przypadku rozumiane jest to jako brak dekoracji malowanych czy drukowanych. Odciskanie kształtów w formie nie wykluczało dekoracji reliefowych lub aplikacji plastycznych.

${ }^{10}$ Zestawienie ze względu na obszerność zagadnienia nie zamyka katalogu wszystkich rodzajów zdobień, jednak wskazuje główne grupy tych wyrobów.
} 

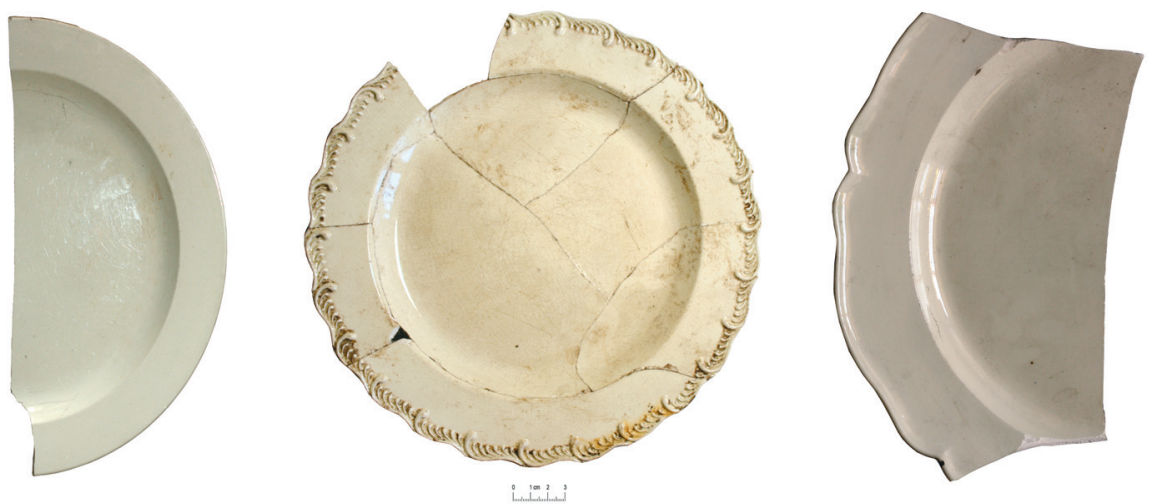

Ryc. 6. Gdańsk, ul. Wałowa 56. Fragmenty talerzy z fajansu delikatnego: 1,3-pearlware; 2 - creamware (fot. J. Dąbal)

Fig. 6. Gdańsk, 56 Wałowa st. Fragments of faience: 1, 3-pearlware plates; 2 - creamware plate (photo by J. Dąbal)

(Barker 1990; Brooks 2005, s. 37; Dąbal 2008), z kolei prostymi krawędziami, sygnowane odciskanym stemplem, ,wedgwood" pochodzą z lat 1775-1780, prawdopodobnie z wytwórni J. Wedgwooda lub Stoke on Tees (Towner 1978, s. 219-232). Spodki i czarki bez dekoracji również reprezentują formy z lat 1770-1790 (ryc. 7) (Barker 1990, s. 182). Czajniki do herbaty, najczęściej zachowane jedynie w postaci dziobków lub wylewów, datowane są na ten sam okres (ryc. 7). Wazy były powszechne w XIX wieku (ryc. 8); chronologię egzemplarzy z Gdańska można określić na 1. ćwierć tego stulecia (Thijssen 1993, s. 292; Bartels 1999, s. 923).

Wyroby malowanie podszkliwnie reprezentują wyłącznie naczynia do picia kawy i herbaty (ryc. 9). Na czarkach i spodkach znajdują się, wykonane błękitem kobaltowym, przedstawienia chińskich krajobrazów w połączeniu z motywami roślinnymi. Chronologię tych egzemplarzy można wyznaczyć na lata 70.-80. XVIII wieku (Barker 1990, s. 198; Thijssen 1993, s. 294; Bartels 1999, s. 889).

Wśród naczyń dekorowanych podszkliwnie wielobarwnie przy użyciu gąbki lub podobnego narzędzia wyróżniono dwa rodzaje zdobień: szylkretowe (Tortoiseshell) i mokka (Mocha). Pierwsze wykonywane było w kolorach: żółtym, fioletowym i zielonym. W badanych materiałach znajduje się ono na dzbankach, dzbankach do herbaty, czarkach i spodkach (ryc. 10). Chronologię wyrobów pozyskanych w Gdańsku określono na koniec lat 60. i lata 70. XVIII wieku (Barker 1990, s. 194). Inspiracją dla drugiego rodzaju zdobień była faktura agatu mszystego sprowadzanego z Mukha w Jemenie, utworzona przez naniesienie specjalnego roztworu z tabaki kolorowanej tlenkiem żelaza ${ }^{11}$ (Rickard 2006, s. 46).

${ }^{11}$ Badania specjalistyczne zostały przeprowadzone przez prof. Stephena W. Morrisa z fundacji „The Experimental Nonlinear Physics Group” (http://www.physics.utoronto.ca/ smorris/edl/ mochaware/ mochaware.html). 

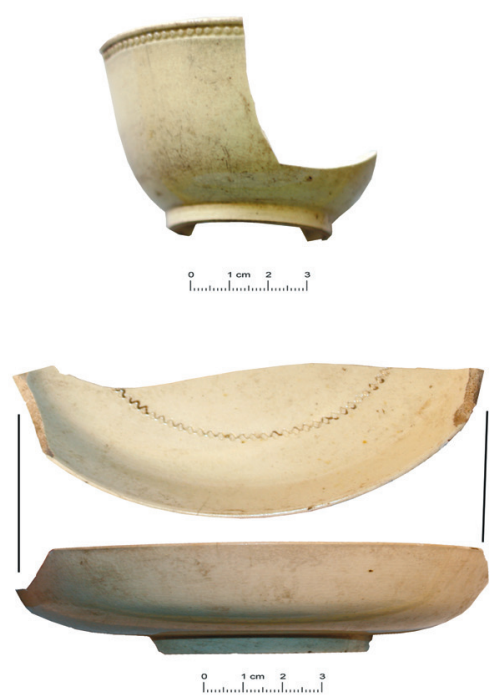
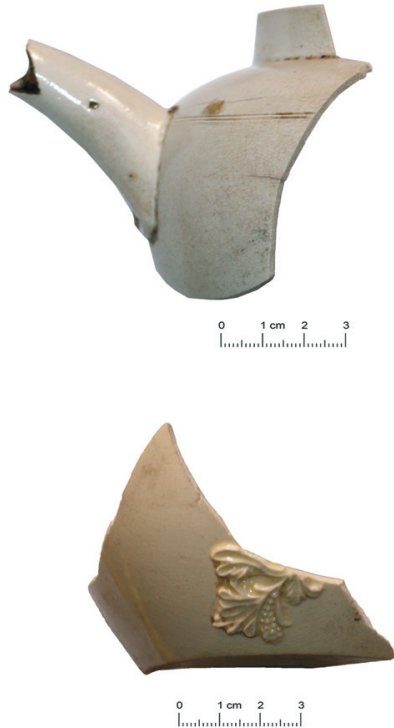

Ryc. 7. Gdańsk, ul. Wałowa 56. Fragmenty naczyń do herbaty z fajansu delikatnego (fot. J. Dąbal)

Fig. 7. Gdańsk, 56 Wałowa st. Fragments of creamware vessels for serving tea and coffe (photo by J. Dąbal)

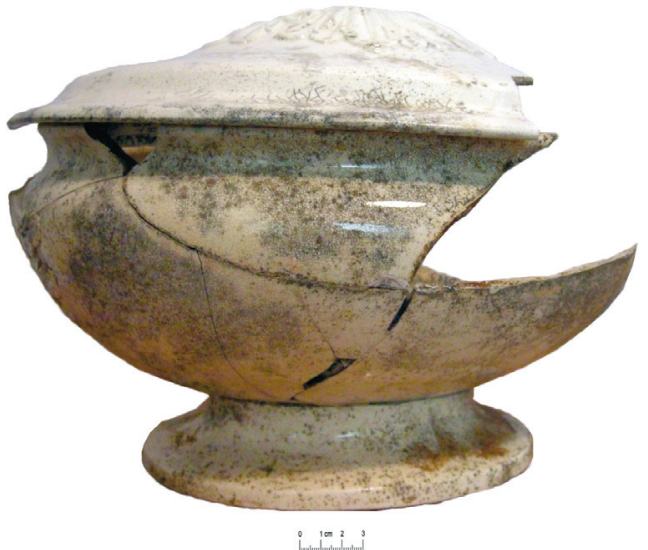

Ryc. 8. Gdańsk, ul. Szafarnia 6, 8a, 8b, 9/ /Angielska Grobla 1. Waza z fajansu delikatnego (fot. J. Dąbal)

Fig. 8. Gdańsk, 6, 8a, 8b, 9 Szafarnia st./1 Angielska Grobla st. Creamware ceramic vaze (photo by J. Dąbal)

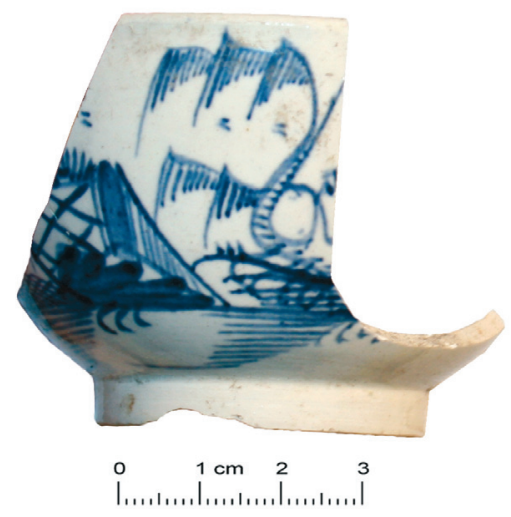

Ryc. 9. Gdańsk, ul. Wałowa 56. Fragment czarki z fajansu delikatnego, malowanej podszkliwnie (fot. J. Dąbal)

Fig. 9. Gdańsk, ul. Wałowa 56. Fragments of underglaze painted cream-ware teacup (photo by J. Dąbal) 
Wśród gdańskich egzemplarzy wyróżniono dwa rodzaje motywów wykonanych szczoteczką i gąbką podczas wolnego obracania naczyń na kole lub na naczyniach odwróconych do góry dnem; są to motywy dendroidalne i tzw. algi (ryc. 11) (Rickard 2006, s. 49-50). Dekoracje typu mokka w prezentowanych materiałach stwierdzono przede wszystkim na płaskich lub głębokich miskach. Jako pierwsza ten rodzaj dekoracji wprowadziła manufaktura Lakin and Pool w latach 80. XVIII wieku, jednak na szerszą skalę naczynia te wytwarzane były w wytwórni Burslem w latach 1796-1828 (Rickard 2006, s. 51).

Kolejny rodzaj dekoracji występującej w gdańskich materiałach to marmoryzowanie. Był on stosowany na wyrobach włoskich, niemieckich, a także na obszarze dzisiejszej Polski w Miechocinie, od XVII wieku. Na fajansach delikatnych pojawiała się pod koniec lat 60. XVIII wieku (Barker 1990, s. 202). Zdobienie wykonywano na biskwicie, na wolno obracającym się kole, w kolorach pomarańczowym, białym, czerwonym lub brązowym. Marmoryzowanie stało się powszechne szczególnie w latach 70. XVIII wieku (Barker 1990, s. 202). $\mathrm{W}$ analizowanych materiałach naczynia dekorowane tą technika reprezentowane są nielicznie, głównie przez miski (ryc. 12), które można datować na lata 70.-80. XVIII wieku (Barker 1990, s. 273, 202).

Wśród naczyń malowanych przykrawędnie podszkliwnie najliczniejszą grupą stanowią elementy zastawy stołowej; najczęściej są to duże, płytkie i głębokie talerze o kołnierzach zakończonych krawędzią muszelkową odciskaną $\mathrm{z}$ formy. Dodatkowo w celach estetycznych stosowano malowanie w kolorach niebieskim i zielonym. Analiza talerzy z Gdańska pozwoliła wyróżnić kilka wariantów tych dekoracji. Prawdopodobnie starsze egzemplarze, z lat 80. XVIII wieku (Sussman 1977, s. 106), mają krawędzie bardzo nieregularne, a także dodatkowe zdobienie w postaci odciskanych długich i szerokich linii na kołnierzu. Występują one w kolorystyce ciemnoniebieskiej i zielonej (ryc. 13: 1); farbę od strony lustra nałożono w sposób stylizujący postrzępienie. Z latach 90 . XVIII wieku pochodzą naczynia z krawędzią w postaci bardzo regularnych, szerokich półokręgów, nieregularnie malowane na niebiesko (ryc. 13: 2). Kolejna grupa wyrobów to talerze o wciąż regularnej, jednak bardzo gęsto utworzonej krawędzi muszelkowej (ryc. 13: 3). Malowane na jasnoniebiesko pasmo podkreślające tą krawędź jest nieco szersze niż w przypadku wyżej opisanych egzemplarzy. Naczynia pochodzą z końca XVIII i 1. ćwierci XIX wieku (Thijssen 1993, s. 294). Wskazówką dla określania chronologii wyrobów malowanych przykrawędnie podszkliwnie może być również zabarwienie farby $-\mathrm{w}$ latach 80 . XVIII wieku stosowano intensywny ciemnoniebieski barwnik, podczas gdy około lat 20. XIX wieku bardzo jasny (Sussman 1977, s. 108).

Malowanie naszkliwne było szeroko stosowane od lat 20. XVIII wieku, przy czym największą popularność technika taka osiągnęła w latach 40.-70. XVIII wieku (Barker 1990, s. 204). Po tym okresie malowanie naczyń było stopniowo 
zastępowane dekoracjami drukowanymi. Wśród wyrobów z Gdańska egzemplarze malowane naszkliwnie najczęściej mają dekoracje roślinne; w większości są to spodki i czarki do picia kawy i herbaty (ryc. 14). Można je datować od lat 60. do końca 70. XVIII wieku (Barker 1990, s. 204; Thijssen 1993, s. 290).

W analizowanym zbiorze znalazło się tylko jedno naczynie zdobione techniką „inkrustowanego agatu” (inlaid agate) - czajnik na herbatę (ryc. 15). Powierzchnia tych wyrobów pokryta jest zdobieniem imitującym agat ${ }^{12}$ (Rickard 2006, s. 20). Podczas ich wytwarzania lekko podsuszone egzemplarze pokrywano kilkoma kolorami, a następnie przy użyciu narzędzia przypominającego grzebień rozprowadzano farbę w różnych kierunkach (Rickard 2006, s. 24). Formy identyczne do gdańskich wykonywano w wytwórni RA Wood Burslem; są one dość dokładnie datowane na 1780 rok (Rickard 2006, s. 30). Ogólnie dla tak zdobionych naczyń górną granicę chronologiczną wskazuje się na 1. dekadę XIX wieku (Rickard 2006, s. 24)

Nadruk na naczyniach fajansowych stosowano w latach 60. i wczesnych 70. XVIII wieku (Samford 1997, s. 2). Wcześniej, od lat 50. XVIII wieku, występował na płytkach ściennych i porcelanie. Wyróżnia się dwa sposoby wykonywania nadruków: pierwszy - podszkliwny na biskwicie oraz drugi - naszkliwny, który mógł być wykonywany na ciepło lub na zimno (Samford 1997, s. 2-4). Popularność nadruków utrzymała się od lat 90. XVIII stulecia przez cały XIX wiek. Najwcześniejsze wykonywano przede wszystkim w kolorach: niebieskim, czarnym i odcieniach czerwieni i brązu (Samford 1997, s. 20). Po 1815 roku zaczęto stosować również inne barwy - zielone, fioletowe, lawendowe oraz morwowe. Wczesne egzemplarze drukowane mają bardzo intensywne zabarwienie, młodsze tonowane są do jaśniejszych. Wytwórnie Staffordshire do tej pory bardzo dokładnie określają odcienie koloru niebieskiego wykorzystywanego do dekorowania ${ }^{13}$ (Copeland 2009, s. 24).

W opisywanym zbiorze wyróżniono kilka rodzajów dekoracji wykonanych techniką druku. W literaturze przedmiotu tematyka takich przedstawień była kilkukrotnie podejmowana z odmiennych perspektyw (Prentice 1994; Samford 1997; Brooks 1997; 1999; 2010; 2012; Lucas 2003). W odniesieniu do opisywanych wyrobów posłużono się podziałem stworzonym przez Patricie Samford (1997), uzupełniając go w oparciu o nowsze publikacje ${ }^{14}$. Wśród analizowanych naczyń wyróżniono centralnie umieszczone dekoracje: chińskie lub chinoizujące, brytyjskie widoki, historyczne lub marynistyczne, krajobrazy i sceny sielskie oraz przedstawienia wraz z dedykacjami na specjalną okazję̨5 (Samford 1997, s. 17; Prentice 1994).

12 Tak tego typu naczynia zostały przedstawione przez J. Wedgwooda.

${ }_{13}$ Przykładowe odcienie niebieskiego: królewski, ultramaryna, cyjanowy, arabski, mandaryński.

${ }^{14}$ Przeprowadzona prezentacja nie stanowi ostatecznego podziału dekoracji, jest jedynie punktem odniesienia w celu wstępnego ich uporządkowania.

15 Tą grupę na podstawie źródeł z Gdańska wyróżniła autorka. 


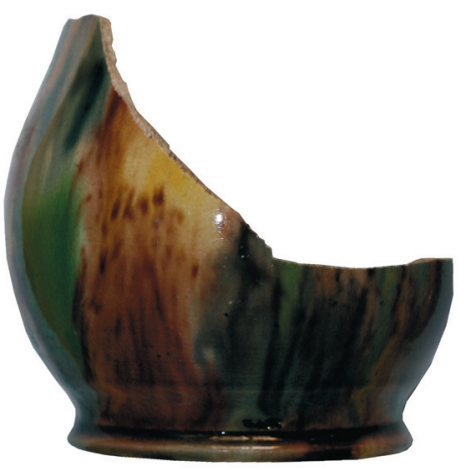

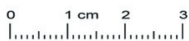

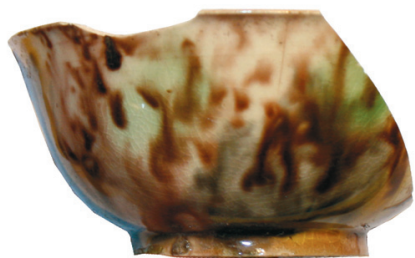

$\begin{array}{lll}0 & 1 \mathrm{~cm} & 2 \\ 1 & 3\end{array}$

Ryc. 10. Gdańsk, ul. Wałowa 56. Fragmenty naczyń fajansowych: 1 - dzbanek; 2 - czarki o powierzchniach szylkretowych (fot. J. Dąbal)

Fig. 10. Gdańsk, 56 Wałowa st. Fragments of faience vessels: 1 - tortoiseshell pitcher; 2 - tortoiseshell teacup (photo by J. Dąbal)
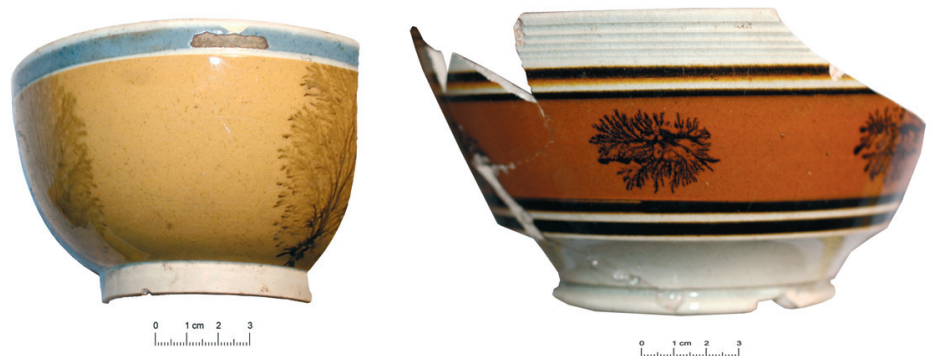

Ryc. 11. Gdańsk, ul. Wałowa 56. Fragmenty fajansowych misek z dekoracją typu mokka (fot. J. Dąbal)

Fig. 11. Gdańsk, 56 Wałowa st. Fragments of mochaware bowls (photo by J. Dąbal)

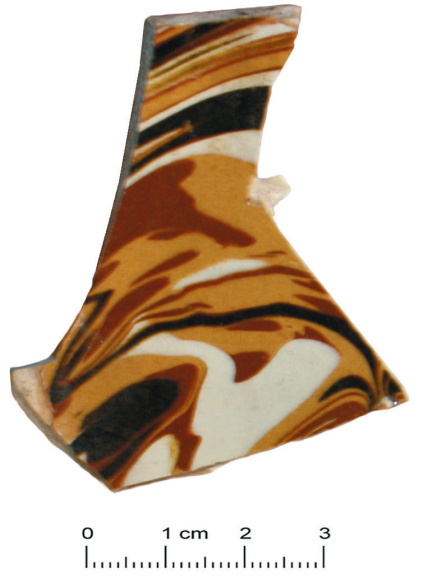

Ryc. 12. Gdańsk, ul. Wałowa 56. Fragment miski o powierzchni marmoryzowanej (fot. J. Dąbal)

Fig. 12. Gdańsk, 56 Wałowa st. Fragment of pottery agateware bowl (photo by J. Dąbal) 

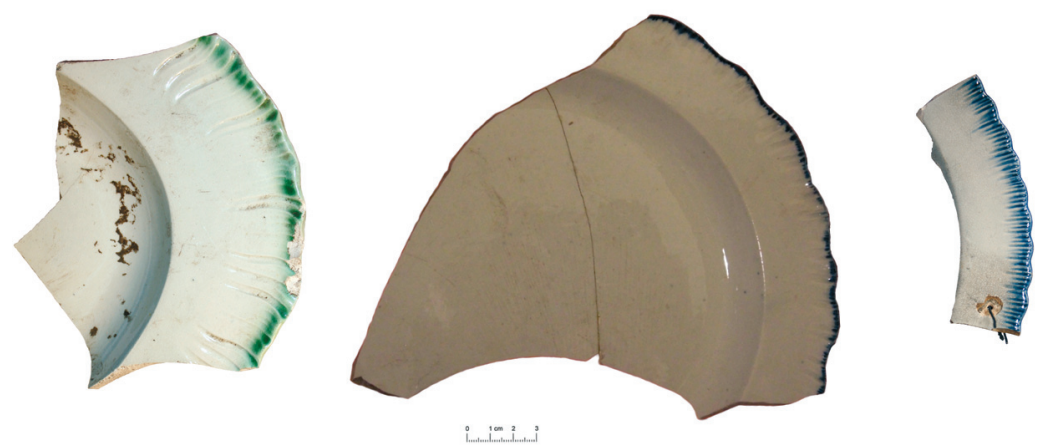

Ryc. 13. Gdańsk, ul. Wałowa $56(1,3)$ oraz ul. Szafarnia 6, 8a, 8b, 9/Angielska Grobla 1 (2). Fragmenty fajansowych talerzy przykrawędnie malowanych (fot. J. Dąbal)

Fig. 13. Gdańsk, 56 Wałowa st. $(1,3)$ and 6, 8a, 8b, 9 Szafarnia st./1 Angielska Grobla st. (2). Fragments of shell edge pearlware plates (photo by J. Dąbal)
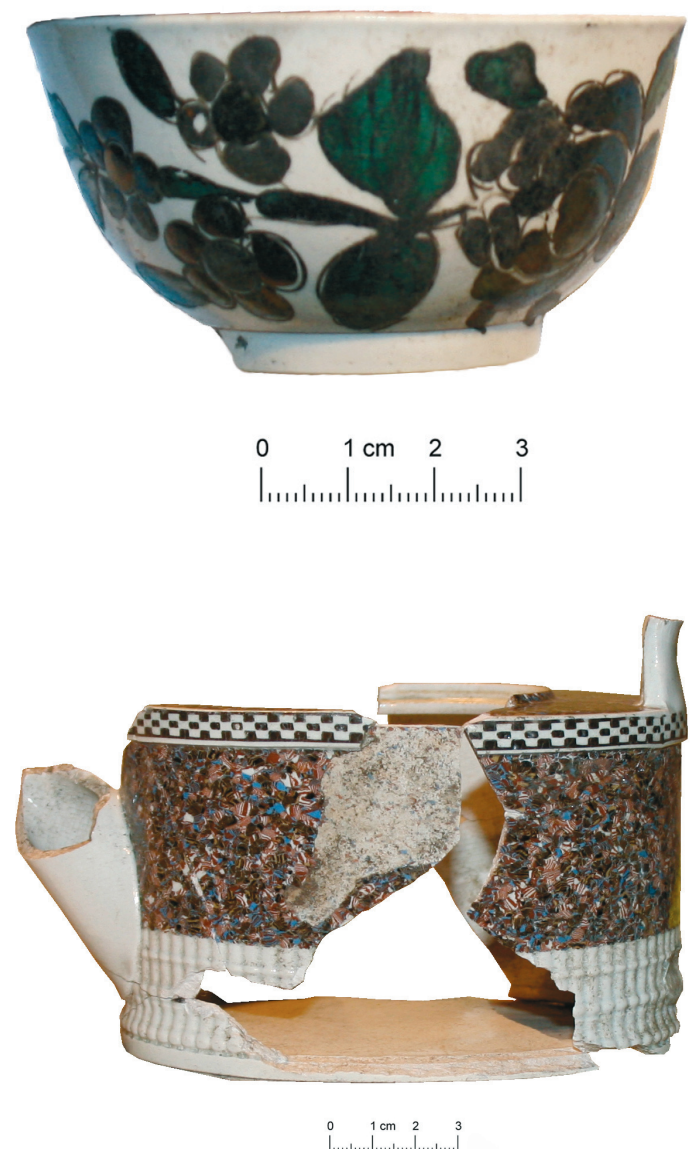

Ryc. 14. Gdańsk, ul. Wałowa 56. Fajansowa czarka malowana naszkliwnie (fot. J. Dąbal)

Fig. 14. Gdańsk, 56 Wałowa st. Creamware cup painted overglaze (photo by Dąbal)

Ryc. 15. Gdańsk, ul. Wałowa 56. Fragment czajnika o powierzchni dekorowanej techniką typu inkrustowany agat (fot. J. Dąbal)

Fig. 15. Gdańsk, 56 Wałowa st. inland agate teapot (photo by J. Dąbal) 
Dekoracje chińskie lub chinoizujące stanowią naśladownictwa przedstawień na chińskiej porcelanie; wykonywano je techniką nadruku naszkliwnego w odcieniach błękitu. Na naczyniach z Gdańska odnotowano najbardziej powszechne motywy występujące na lepszych gatunkowo fajansach delikatnych (pearlware), nazywanych przez wytwórców ze Staffordshire China glaze (ryc. 16: 1, 2). Reprezentowane w zbiorze naczynia dekorowane motywem pagody na tle drzew wierzbowych nazywane są blue willow ware (ryc. 16: 1) (Samford 1997, s. 7-8, 17; Brooks 2005, s. 44; Brooks, Rodríguez 2012, s. 78).

Przedstawienia brytyjskich widoków w gdańskich materiałach występują na talerzach, spodkach i filiżankach (ryc. 16: 3). Większość tych dekoracji to wiejskie pejzaże i architektura, drukowane głównie na niebiesko lub czarno. Były one najbardziej powszechne w latach 1815-1840. Chronologię egzemplarzy z Gdańska należy określić na 1. ćwierć XIX wieku (Samford 1997, s. 9).

Wśród dekoracji historycznych i marynistycznych wyróżniono kilka przedstawień ilustrujących główne wydarzenia i miejsca w Anglii. Do najciekawszych należą naczynia (spodek i miseczka) ze specjalnym kolorowym nadrukiem, prezentujące alegorie zakończenia wojen brytyjsko-francuskich podczas Rewolucji Francuskiej ${ }^{16}$ (ryc. 17). Brytyjczycy nieco odmienne ujmują wagę poszczególnych wydarzeń tej kampanii, za istotne podają daty $1793^{17}, 1798^{18}, 1802^{19}$ (Rutherford 1996, s. XXVIII, XXXV). Dla upamiętnienia tych wydarzeń i upodobanej przez Brytyjczyków politycznej propagandy motywy ujęte zostały również na naczyniach ceramicznych.

Dekorację marynistyczną stwierdzono na zachowanym w niewielkim fragmencie dzbanka. Przedstawia ona część masztów sygnalizacyjnych (umieszczonych po lewej stronie) latarni morskiej na Wzgórzu Bidston w Liverpoolu (ryc. 18: 1) (Prentice 1994, s. 90). Chronologię naczynia wykonanego w Liverpoolu należy wskazać na lata 90. XVIII wieku (Prentice 1994, s. 90-91).

Dekoracje sielankowe reprezentowane są przez przedstawienia postaci przy pracy, często ze zwierzętami, w czasie odpoczynku czy rozrywki. Bardziej powszechne w zbiorach gdańskich wydają się być te związane z sielskim odpoczynkiem mieszkańców miast (ryc. 19). Podobnie dekorowane naczynia pochodzą z wytwórni J. Wedgwooda ${ }^{20}$, z lat 70. XVIII wieku oraz z Liverpoolu ${ }^{21}$. Największa popularność tych wyrobów przypadała na lata 1819-1836 (Samford 1997, s. 13-14).

${ }^{16}$ Interpretacja tego przedstawienia możliwa była przy udziale dr. Davida Barkera, któremu dziękuję za udostępnienie niepublikowanych źródeł do porównań.

17 Wypowiedzenie konfliktu między Wielką Brytanią a Francją.

${ }_{18}$ Zwycięstwo floty admirała Horatio Nelsona w zatoce Aboukir.

19 Pokój w Amiens - 27 marca 1802 roku.

${ }^{20}$ Drukowane na czerwono.

${ }^{21}$ Drukowane na czarno. 

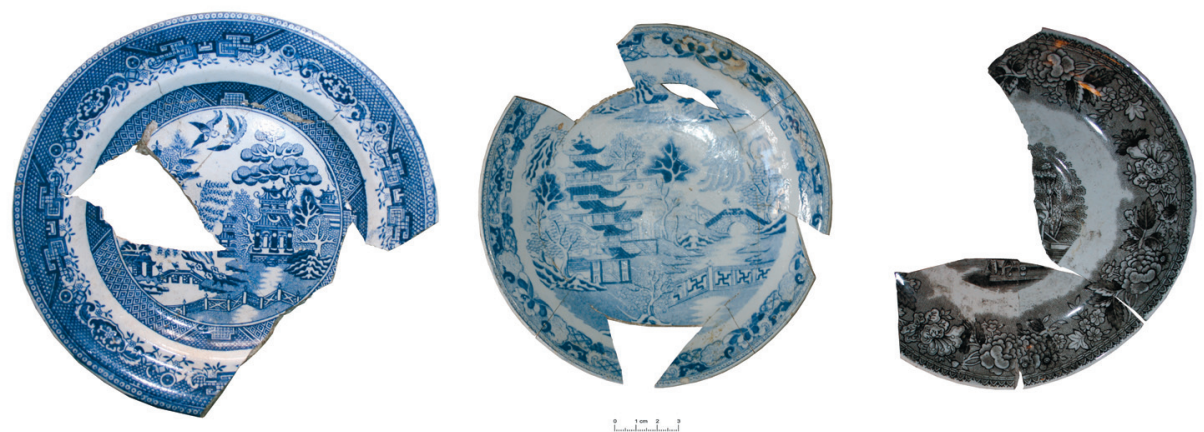

Ryc. 16. Gdańsk, ul. Wałowa 56. Fragmenty fajansowych talerzy dekorowanych techniką druku (fot. J. Dąbal)

Fig. 16. Gdańsk, 56 Wałowa st. Fragments of transfer printed plates (photo by J. Dąbal)

Ryc. 17. Gdańsk, ul. Wałowa 56. Fragment fajansowego talerza dekorowanego techniką druku wielobarwnego (fot. J. Dąbal)

Fig. 17. Gdańsk, 56 Wałowa st. Fragment of creamware, polychrome transfer printed ware (photo by J. Dąbal)

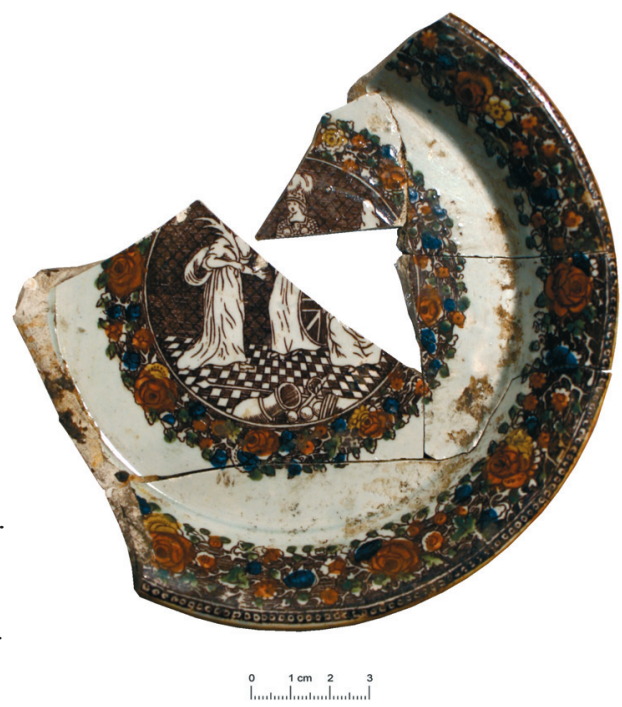

Ryc. 18. Gdańsk, ul. Wałowa 56. Naczynia fajansowe: 1 - fragment dzbana; 2 - fragment miski (fot. J. Dąbal)

Fig. 18. Gdańsk, 56 Wałowa st. Fragments of creamware vessels: 1 - pitcher; 2 - bowl (photo by J. Dąbal)
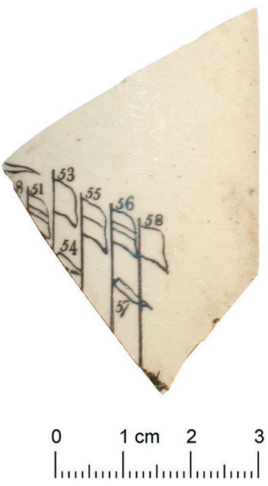
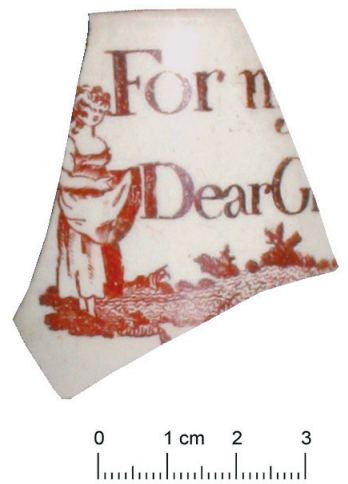

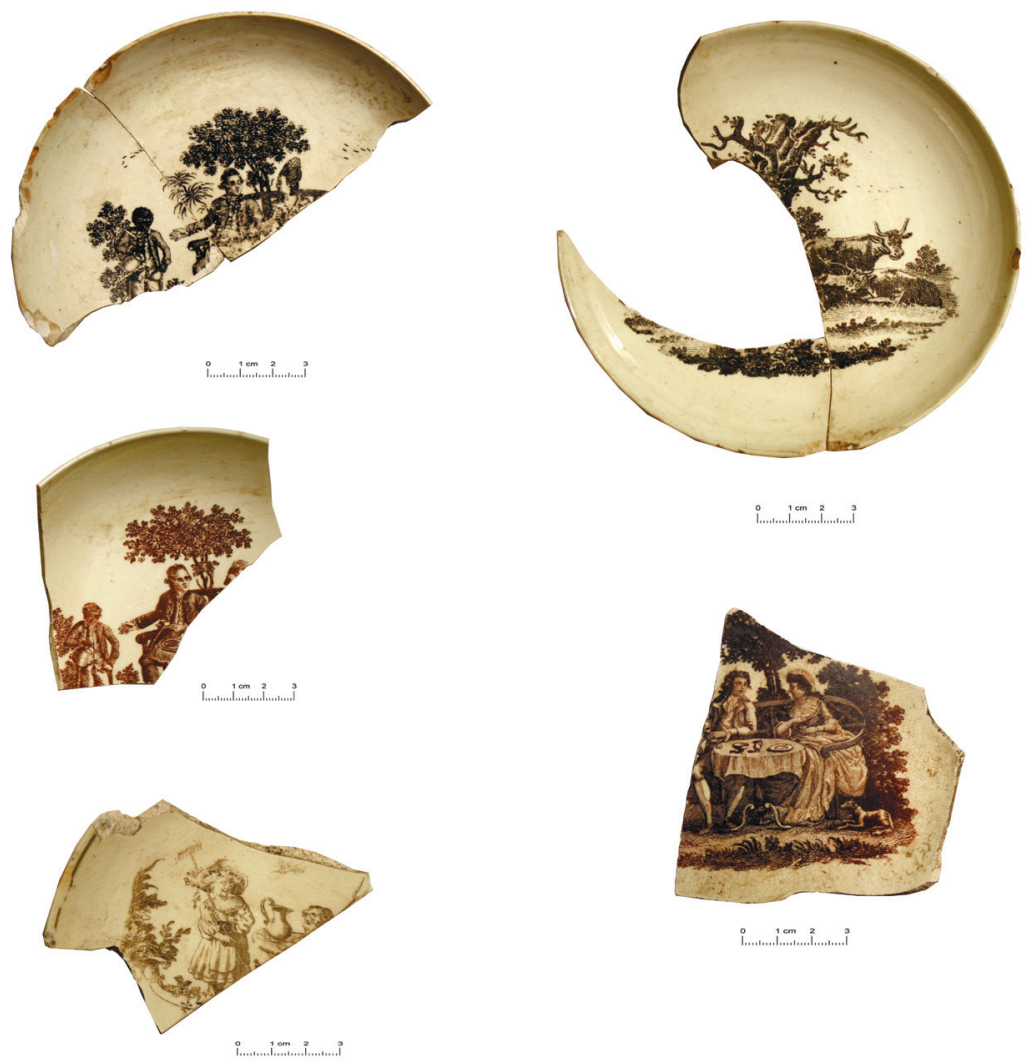

Ryc. 19. Gdańsk, ul. Wałowa 56. Fragmenty fajansowych spodków dekorowanych techniką druku (fot. J. Dąbal)

Fig. 19. Gdańsk, 56 Wałowa st. Transfer printed creamware saucers (photo by J. Dąbal)

Ostatnią grupą dekoracji drukowanych są te wykonywane z okazji specjalnych wydarzeń lub dla określonej grupy osób. Wśród materiałów z Gdańska znalazło się między innymi naczynie z dedykacją dla babci lub wnuczki (ryc. 18: 2). Analogiczne naczynia pochodzą z lat 90. XVIII wieku (Draper 2001, s. 50). Tego rodzaju aplikacje częściej odnotowywane są na egzemplarzach pochodzących z wytwórni w Liverpoolu, znacznie rzadziej z wytwórni w Staffordshire (Draper 2001, s. 50).

\section{Naczynia czarne i czerwone (blackware, redware)}

Naczynia te wykonywano z oczyszczonych glin żelazistych z niewielką domieszką glin białych (Barker 1990, s. 17). Czarna barwa ich powierzchni, jak wskazują analizy przeprowadzone na materiałach z Cheshire, wynika z wysokiego stężenia tlenku żelaza (Barker 1986, s. 61). Wyroby te pokrywano ołowiowym szkliwem. 


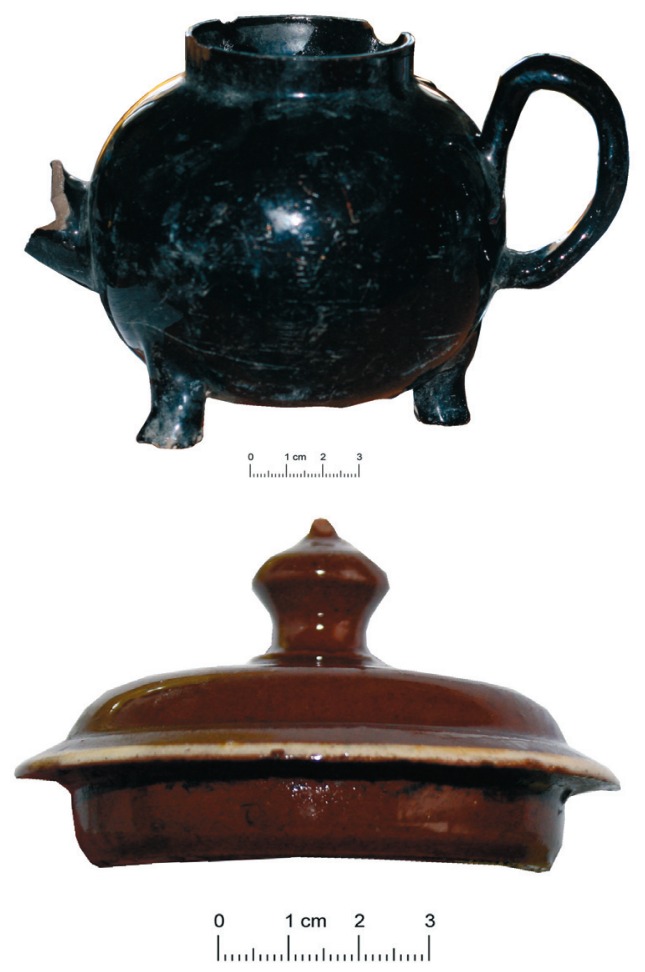

Ryc. 20. Gdańsk, ul. Wałowa 56. Naczynie czarne (blackware) - czajnik na herbatę na trzech nóżkach (fot. J. Dąbal)

Fig. 20. Gdańsk, 56 Wałowa st. Blackware tea-pot (photo by J. Dąbal)

W materiałach z Gdańska tę kategorię reprezentują czajniki i pokrywki. Czajniki o czarnych powierzchniach mają płaskie dna i trzy nóżki (ryc. 20). Ten rodzaj wyrobów można datować od lat 50. do 80. XVIII wieku (Barker 1986, s. 59). Naczynia o czerwonej powierzchni zdobione są białymi pasmami przy krawędziach wylewów lub na zewnętrznych krawędziach pokrywek (ryc. 21). Chronologię tych egzemplarzy określa się na lata 80. XVIII wieku (Barker 1990, s. 271-272).

\section{Jednorodne fajki gliniane}

Wśród wyrobów ceramicznych z Gdańska wyróżnia się grupa fajek angielskich. Najstarsze egzemplarze pojawiły się pod koniec XVI wieku, pojedynczo występowały w XVII wieku, jednak ich liczba w Gdańsku zdecydowanie zwiększyła się pod koniec XVIII i w XIX stuleciu.

Literatura dotycząca angielskich i szkockich fajek jest bardzo bogata, jednak wciąż jeszcze niewyczerpująca. Bardzo ogólny zarys stanu badań nad tymi wyrobami przedstawił David Higgins (2009). Z obszaru dzisiejszej Wielkiej Brytanii znane są liczne stanowiska archeologiczne będące pozostałościami warsztatów fajczarskich, pieców lub miejsc składowania odpadów produkcyjnych. Poszczególne 
ośrodki wytwórcze ujęto w szczegółowym opracowaniu interdyscyplinarnym, prezentującym także modele fajek i nazwiska ich wytwórców. Analizy takie między innymi wykonano dla Londynu, Yorkshire, Glasgow czy Bostonu. Liczne, szczegółowe studia dotyczące wytwórczości poszczególnych ośrodków powodują, że podejmując badania nad tą problematyką należy każdorazowo odnosić się do literatury związanej z danym, bardzo wąskim zagadnieniem. Istotną kwestią są też wciąż jeszcze słabo rozpoznane w Anglii wyroby przeznaczone na eksport. Modele tych fajek często różnią się od powszechnie występujących w miastach angielskich i szkockich w danym okresie, są także odmiennie oznaczane. Z tego powodu, mimo dobrego rozpoznania lokalnej angielskiej wytwórczości, wciąż kłopotliwą jest identyfikacja materiałów spoza obszaru ich wytwarzania.

Z wyjątkiem pracy Davida Atkinsona i Adriana Oswalda (1969), wskazującej ogólną typologię stworzoną na potrzeby materiałów z Londynu, nie ma takiego odnośnika dla całego obszaru Wielkiej Brytanii. Dlatego w niniejszym artykule wzmiankowana typologia będzie punktem odniesienia, jednak poszczególne grupy wyrobów zostały ujęte według rejonu ich produkcji. W świetle aktualnego stanu badań wyróżniono trzy główne obszary produkcyjne, z których pochodzą fajki znalezione w Gdańsku: Londyn, Liverpool oraz Szkocja. Uwzględniając stan badań nad wymienionymi wyrobami, najwięcej uwagi poświęcono słabo znanym $\mathrm{z}$ literatury egzemplarzom $\mathrm{z}$ Liverpoolu.

Występowanie fajek angielskich w zespołach z Gdańska jest bardzo nierównomierne waha się od $1 \%$ do $25 \%$ w obrębie poszczególnych jednostek stratygraficznych ${ }^{22}$. Baza danych uzyskana $\mathrm{z}$ analizowanych stanowisk jest wciąż niedostatecznie reprezentatywna dla określenia ogólnych tendencji występowania tej kategorii źródeł w Gdańsku. Wyroby brytyjskie przynajmniej pojedynczo odnotowywane są na każdym gdańskim stanowisku. Do tej pory największa ich liczba pochodzi z obszarów związanych z wodnymi ciągami komunikacyjnymi znajdującymi się po obu brzegach Motławy i jej górnych dopływów. Prawdopodobnie właśnie lokalizacja, a więc zajmowanie danego obszaru przez określone grupy społeczne (zawodowe), determinuje skalę ich występowania.

Fajki londyńskie są jedną z lepiej znanych i opracowanych grup wyrobów, zarówno z perspektywy archeologicznej, jak i archiwalnej (Atkinson, Oswald 1969; Walker 1971; Oswald 1975; Hamilton, Lunn 1984; Tatman 1994). W materiałach z Gdańska wyróżniono główki typu 21, 25 oraz 27 według typologii D. Atkinsona i A. Oswalda (1969, s. 178, 180). Wyroby te sygnowane są literami WM (monogram na główce i nosku), W. Russell (na główce i monogram na nosku) oraz FS (na nosku), licznie występują też egzemplarze niesygnowane (ryc. 22). Chronologię fajek londyńskich, na podstawie kształtu główki, można ogólnie określić na okres od około 1710 do 1820 roku (Atkinson, Oswald 1969, s. 176-181). Sygnowane okazy

${ }^{22}$ Stanowisko przy ulicy Lastadia, podczyszczanie parceli 46 - 1\%, stanowisko przy ulicy Wałowej 56 , warstwa $5333-25 \%$. 

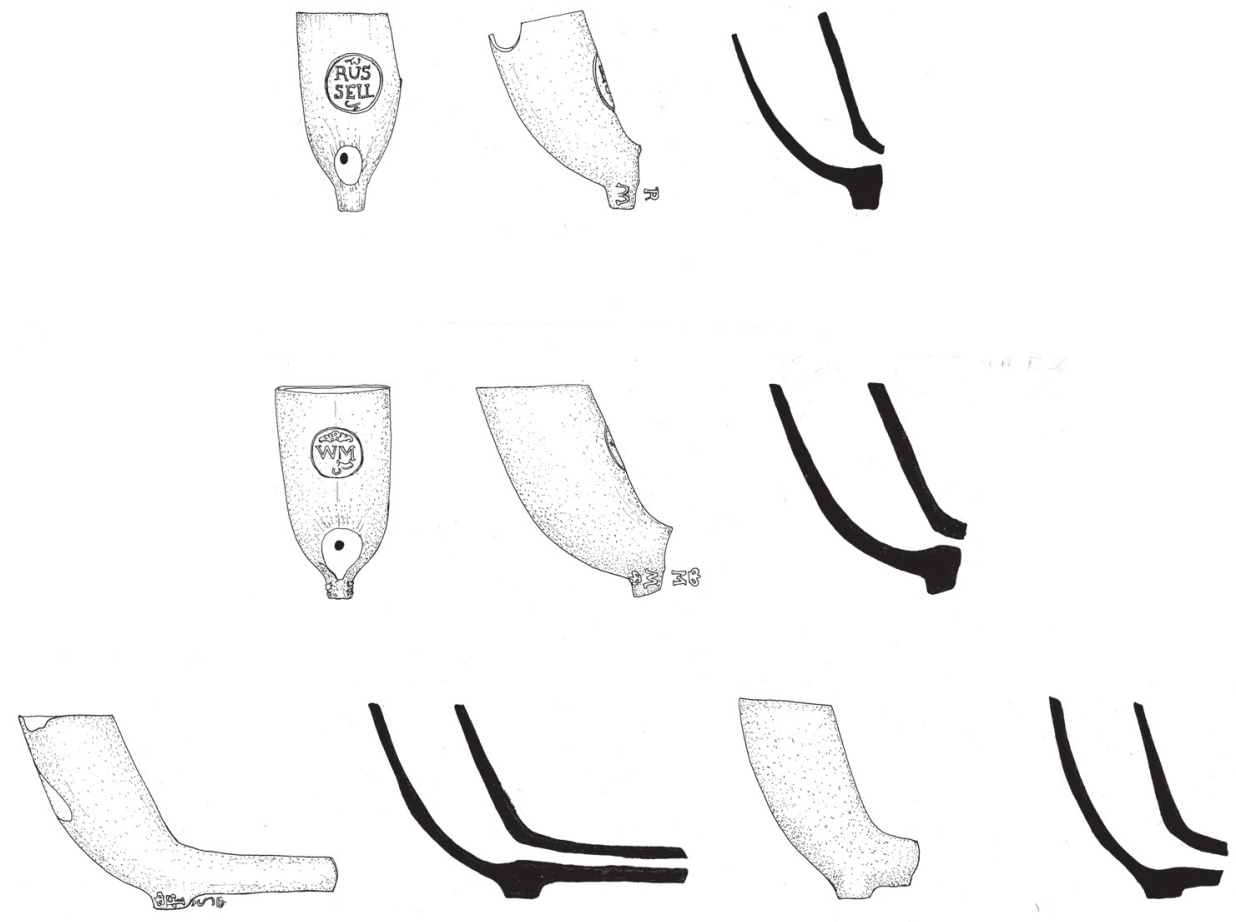

Ryc. 22. Gdańsk, ul. Wałowa 56. Fragmenty fajek londyńskich (rys. L. Rej)

Fig. 22. Gdańsk, 56 Wałowa st. Fragments clay tobacco pipes, bowls (drawing by L. Rej)

pozwalają wskazać kilku londyńskich wytwórców i przybliżyć ich chronologię: FS - Francis Stray (wzmianka w archiwach z 1732 roku), WM - William Manby (wzmianka w archiwach z 1719 roku) (Atkinson, Oswald 1969, s. 213, 215; Higgins 2009, s. 46). Fajka oznaczona nazwiskiem Russell najprawdopodobniej pochodzi z londyńskiej wytwórni Williama Russella, posiadającego warsztat w Green Bank, Wapping, zmarłego przed 1819 rokiem (Atkinson, Oswald 1969; Oswald 1975).

Identyfikacja fajek z Liverpoolu, pozyskanych podczas prac archeologicznych w Gdańsku, wymaga krótkiego wprowadzenia na temat stanu badań tego zagadnienia w Anglii. Jak wyżej wspomniano, fajki te są jedną ze słabiej opublikowanych grup wyrobów angielskich. Głównym powodem jest niewielka liczba szczegółowych badań archeologicznych w obrębie miasta. Można wyróżnić trzy duże $\mathrm{i}$ istotne dla poznania lokalnych liverpoolskich wyrobów stanowiska: w sąsiedztwie kanału znajdującego się przy Muzeum Miasta Liverpool (Canal Links Excavation) (Higgins 2010a) oraz na obszarze doków (Manchester Dock Excavation i Old Dock Excavation), a także zbiór z zasypiska XIX-wiecznych 
tuneli pod budynkami Jospeha Williamsa (Higgins 2010b). Najistotniejszy dla ustaleń odnoszących się do gdańskich wyrobów jest zespół odpadów produkcyjnych pochodzący z badań kanału w Liverpoolu (Canal Links Excavation).

$\mathrm{Na}$ obszarze Gdańska fajki z Liverpoolu zostały dotychczas zidentyfikowane jedynie wśród materiałów z ulicy Wałowej 56 na Starym Mieście. Wśród

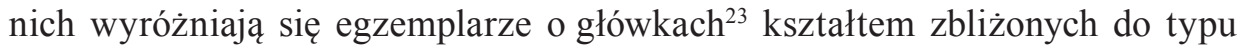
27 (Atkinson, Oswald 1969) z obustronną dekoracją reliefową w postaci ptaka (Liverbird'a) z lewej strony, symboli masońskich z prawej oraz głowy jelenia od góry. Liverbird symbolizuje miasto Liverpool, trudno jednak przyporządkować jego nazwę żyjącym gatunkom, najczęściej jest utożsamiany z kormoranem (McIntyre-Brown 2002, s. 12-23). Od około połowy XIV wieku, na którą datowane jest pierwsze znane przedstawienie Liverbird'a na pieczęci miasta, stanowi on jego stały i powtarzalny symbol. Najczęściej wyobrażany jest trzymając w dziobie algę (Porphyra yezoensis). Na gdańskich fajkach występują dwa rodzaje wymienionych wyżej zdobień (ryc. 23) - pierwsze z przedstawieniem ptaka (Liverbird) umieszczonego na trzech prostych gałązkach roślinnych oraz prawdopodobnie ${ }^{24}$ na trzech $^{25}$ zawiniętych gałązkach. Drugi symbol to cyrkiel wolnomularski w kilku sytuacjach ujmujący literę G, oznaczającą Angielską Wielką Lożę Masońską (Grand Masonic Lodge), która posiadała swoje filie w Manchesterze i Liverpoolu. Należy jednak zaznaczyć, że tak sygnowane fajki wytwarzane były masowo i nie musiały wiązać się z przynależnością do Loży. W przypadku symbolu masońskiego na egzemplarzach z Gdańska wyróżniono dwa rodzaje ujęć.

Przynależność tych wyrobów do wytwórców z Liverpoolu potwierdzają zachowane na cybuchach napisy: R MORGAN LIVERPOOL, T HAYES LIVERPOOL, C KANYON LIVERPOOL. Na szczególną uwagę zasługuje fajka, z której zachowała się zdobiona główka (ryc. 23: 1) oraz sygnowany cybuch; jak dotąd, jest to jedyny taki egzemplarz znany w Europie ${ }^{26}$. Ten model fajki zosta1 wykonany przez Richarda Morgana, którego działalność określa się w szerokich ramach na lata $1790-1845$. Ponieważ pochodzi on z końca XVIII i początku XIX wieku chronologię wyżej wspomnianego egzemplarza można zakreślić na początek działalności wytwórcy ${ }^{27}$.

Drugi wyróżniony wytwórca - Thomas Hayes - pracował w Liverpoolu w latach 1770-1800 (Higgins 2010a, s. 5). Z zespołu odpadów produkcyjnych w Liverpoolu w kontekście znalezisk z analogicznym sygnowaniem występują

\footnotetext{
${ }^{23}$ Wymiary główek: wysokość $42 \mathrm{~mm}$, średnica wylotu $25 \mathrm{~mm}$, wysokość ostrogi $4 \mathrm{~mm}$.

${ }^{24}$ Zachowała się tylko dolna część lewej strony fajki.

${ }^{25} \mathrm{~W}$ tym jedna bez listków.

26 Także w Anglii do tej pory nie natrafiono na tak zachowane fajki.

${ }^{27}$ Wszystkie informacje pochodzą z Bazy Danych wytwórców fajek w Liverpoolu (materiały niepublikowane) stworzonej w oparciu o źródła archiwalne przez dr Davida Higginsa, któremu dziękuję za jej udostępnienie.
} 

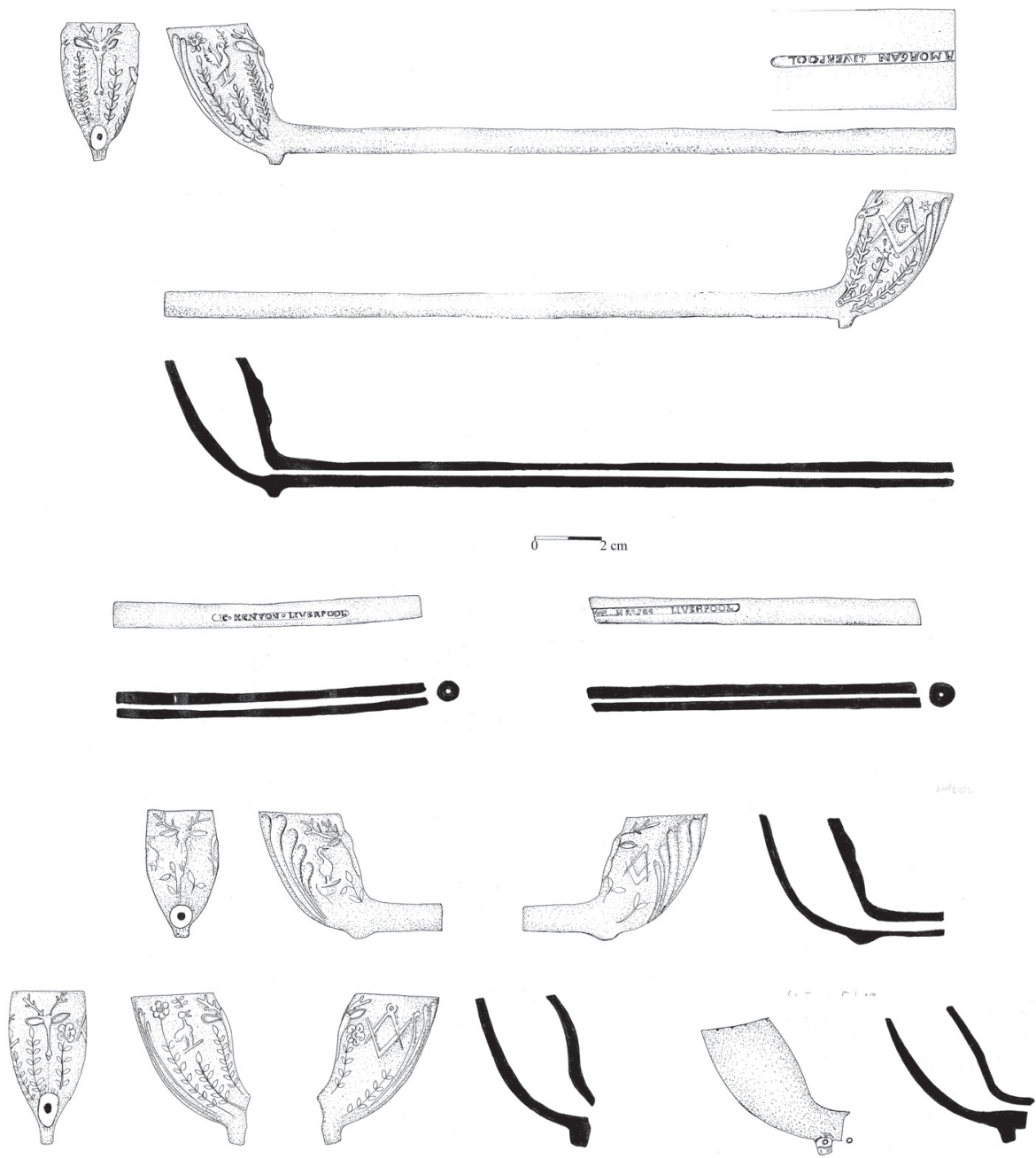

${ }_{0} \mathrm{~cm}$

Ryc. 23. Gdańsk, ul. Wałowa 56. Fragmenty fajek z Liverpoolu (rys. L. Rej)

Fig. 23. Gdańsk, 56 Wałowa st. Liverpool clay tobacco pipes, bowls (drawing by L. Rej)

główki zdobione na drugi wyróżniony sposób ${ }^{28}$ (Higgins 2010a, ryc. 33). Ostatnią wyróżnioną sygnaturą jest oznaczenie Charlesa Kenyon'a, działającego w latach 1781-181729. Do tej pory jego sygnatura znana jest tylko z jednego stanowiska w Dorset (Higgins 2010a, s. 7). W świetle dotychczasowych ustaleń nie udało się atrybuować temu wytwórcy konkretnego modelu fajki.

${ }^{28} \mathrm{Z}$ motywem cyrkla i Liverbird' $a$ umieszczonymi na lekko zawiniętych gałązkach.

${ }^{29}$ Do 1817 roku odnotowany w spisie loży masońskiej (ustalenia dr. Davida Higginsa). 

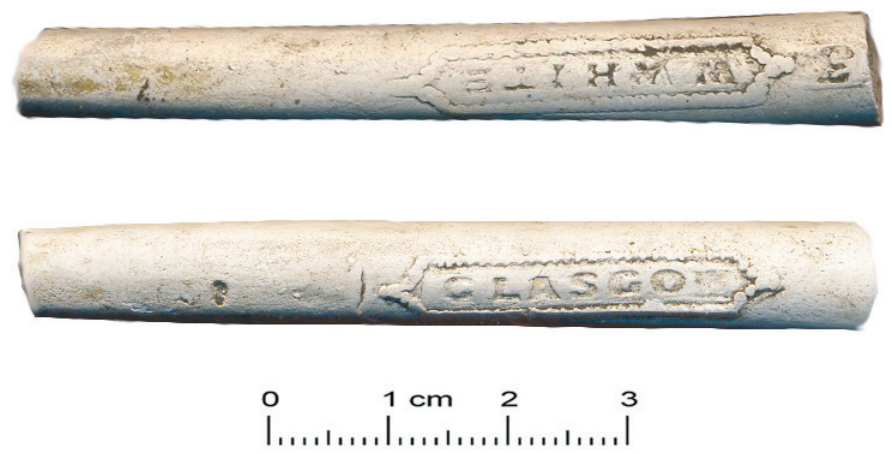

Ryc. 24. Gdańsk, ul. Lastadia. Fragment fajki szkockiej (fot. J. Dąbal)

Fig. 24. Gdańsk, Lastadia st. Scottish clay tobacco pipe, stem (photo by J. Dąbal)

W zespole fajek z Gdańska wyróżniono także jedną główkę, którą przypisano wytwórni w Liverpoolu. Jej kształt można odnieść do trzech typów według D. Atkinsona i A. Oswalda - 26, 27 i 28; jest niższa i węższa od opisanych egzemplarzy zdobionych, ma także dłuższą ostrogę ${ }^{30}$. Na ostrodze, z lewej strony, znajduje się oko - symbol masonerii. Takie egzemplarze pochodzą również z zespołu odpadów produkcyjnych w Liverpoolu. Na tej podstawie proweniencję oraz chronologię gdańskiego okazu wskazano wstępnie na lata 1780-1790 i warsztaty w Liverpoolu (Higgins 2010a, s. 1-4).

Ostatnią grupą fajek z Gdańska są wyroby szkockie. Informacje na ich temat są bogato prezentowane w brytyjskiej literaturze. Dwa główne ośrodki w Szkocji - Glasgow i Edynburg specjalizowały się w wytwarzaniu wyrobów na eksport, głównie do Stanów Zjednoczonych i Kanady, a następnie do Australii (The archaeology 1987).

Wśród analizowanych egzemplarzy wyróżniono tylko jeden cybuch sygnowany . $.3 \mathrm{w}$ WHITE GLASGOW (ryc. 24). Wyroby z podobnymi sygnaturami - 71 w WHITE ${ }^{31}$ oraz (1?)18 WHITE - znane są z innych gdańskich stanowisk z obszaru Starego Miasta i Wyspy Spichrzów (Dyba 2009, s. 432). Natomiast na żadnym nie znaleziono cybuchów z główkami, co utrudnia rozpoznanie całego modelu fajki. Fragment jednego okazu pochodzi z manufaktury Williama White'a w Glasgow (Gallagher 1987a, s. 27). Z roku 1900 znane są katalogi cen fajek W. White \& Sons (Gallagher 1987b, s. 81-84). Firma utrzymywała popularne modele bardzo długo, zatem na podstawie tych danych nie można zbyt dokładnie określić chronologii znalezisk z Gdańska. Sposób oznaczenia oraz niska numeracja ${ }^{32}$ opisywanych modeli może wskazywać, że pochodzą one z 2. połowy XIX wieku (Gallagher 1987a, s. 27; 1987b, s. 81-84).

\footnotetext{
${ }^{30}$ Wymiary główki: wysokość $38 \mathrm{~mm}$, średnica wylotu: $20 \mathrm{~mm}$, wysokość ostrogi: $5 \mathrm{~mm}$.

${ }^{31}$ Badania przy ulicy Tartacznej/Pańskiej (opracowanie J. Dąbal).

${ }^{32}$ Numer umieszczony przed nazwiskiem White oznacza określony model.
} 


\section{Ceramika budowlana}

Wśród tej kategorii wyrobów pochodzących z Anglii i Szkocji wyróżniono cegły oraz elementy systemu wodno-kanalizacyjnego. Cegły ogniowe o przykładowych wymiarach: $60 \times 110 \times 216 \mathrm{~mm}$ oraz $60 \times 111 \times 225 \mathrm{~mm}$, sygnowane są napisem RAMSAY (ryc. 25). Wytwórnia G. H. Ramsay \& Company działała w latach 1789-1925 w Newcastle-on-Tyne (Gurcke 1987, s. 73). Niewykluczone, że cegły zostały zastosowane wtórnie w wypełniskach fundamentów pod Magazyn Rafinerii Cukru (Westpreussischen Zucker Raffinerie Ottona Wanfrieda) przy ulicy Jaglanej 3/5. Założenie powstało przed rokiem 1902. Innym obiektem, do budowy którego użyto cegieł z sygnaturą RAMSAY jest kilkakrotnie przebudowywana w latach 1854-1897 mydlarnia J. J. Bergera, znajdująca się przy ulicy Służebników 18-22 (Dąbal 2009; 2012).

Kolejnym wyrobem importowanym ze Szkocji są ceramiczne (kamionkowe) rury wodociągowe (ryc. 26). Jeden z elementów, o niegwintowanym łączeniu, sygnowany jest napisem PRESTONGRANGE. W Prestongrange znajdowały się fabryki przemysłu budowlanego oraz chemicznego. Od roku 1874 w wytwórniach wykonywano ceramiczne rury wodociągowe ${ }^{33}$. W Gdańsku system wodociągowy zbudowany z tych elementów komunikował ze sobą budynki wspomnianej wyżej Rafinerii Cukru przy ulicy Jaglanej 3/5. Musiał być zbudowany niedługo po 1902 roku, kiedy zagospodarowywano tę część obszaru fabryki (Dąbal 2009).

Brytyjskie wyroby ceramiczne na gdańskim rynku produktów

W oparciu o przedstawione przykłady angielskich i szkockich wyrobów ceramicznych można wskazać kilka głównych cech tych produktów na rynku gdańskim w okresie od około połowy XVIII do końca XIX wieku.

Przeprowadzone badania wykazały zwiększanie się liczby angielskich naczyń ceramicznych od 3. ćwierci XVIII wieku do początków XIX wieku. Największy zbiór tych wyrobów pochodzi z okresu od lat 70. XVIII wieku do początku XIX stulecia. Reprezentują one wyłącznie zastawę stołową, w tym: talerze, zestawy do picia kawy i herbaty, a także wazy. W większości są to egzemplarze niedekorowane oraz malowane przykrawędnie, mniej licznie odnotowano wyroby drukowane, malowane i o powierzchniach barwionych. Takie proporcje mogą sugerować, że ta druga grupa naczyń stanowiła mniej dostępną, a więc nieco droższą część. Obserwacje odnoszące się do jakości naczyń angielskich użytkowanych w Gdańsku potwierdzają amerykańskie i angielskie portowe księgi rachunkowe. Obecność licznych form naczyń przeznaczonych do picia kawy czy herbaty,

${ }^{33}$ Biuletyn Informacyjny Muzeum Prestongrange: Sourcing, brickmaking, salting and chemicals at Prestongrange: wydany przez Scottish Mining Museum Trust. 

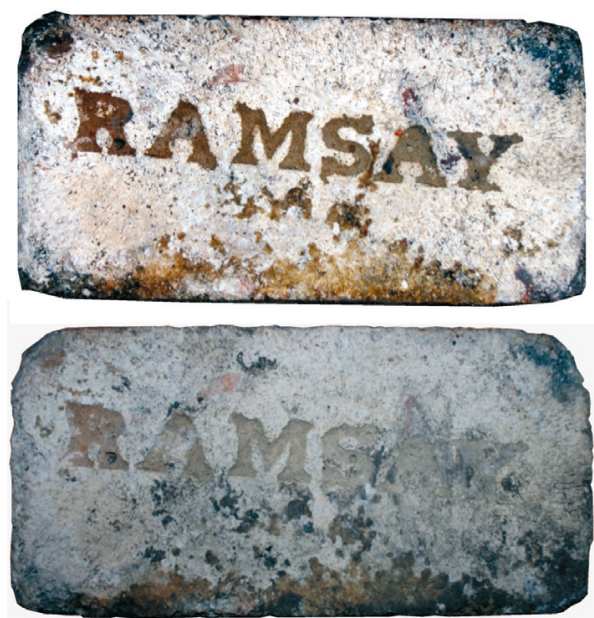

Ryc. 25. Gdańsk, ul. Podwale Przedmiejskie 519/17 (1) oraz ul. Jaglana 3/5 (2). Cegły z sygnaturą RAMSAY (fot. J. Dąbal)

Fig. 25. Gdańsk, 519/17 Podwale Przedmiejskie st. (1) and 3/5 Jaglana st. (2). Firebricks with RAMSAY mark (photo by J. Dąbal)
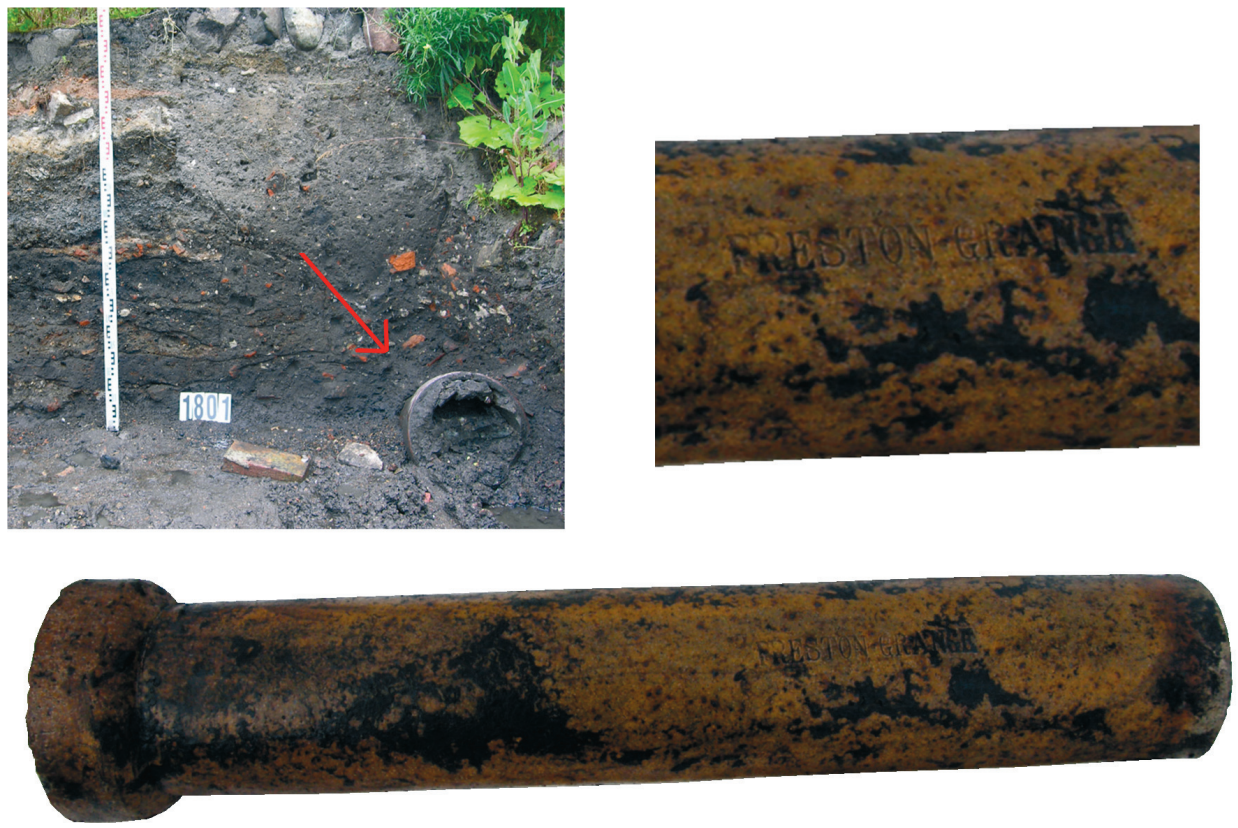

Ryc. 26. Gdańsk, ul. Jaglana 3/5. Kamionkowa rura z sygnaturą PRESTONGRANGE, widoczna we wschodnim profilu stanowiska (fot. J. Dąbal)

Fig. 26. Gdańsk, 3/5 Jaglana st. Stoneware water-pipe with PRESTONGRANGE mark, seen in eastern site profile (photo by J. Dąbal) 
reprezentowanych przede wszystkim przez tańsze, mniej dekoracyjne wyroby, sugeruje powszechność spożywania tych napojów w Gdańsku w 2. połowie XVIII wieku. Z kolei występowanie waz (których chronologię określono na początki XIX wieku) wskazuje, że w Gdańsku zaadaptowano modę podawania posiłków na sposób angielski ${ }^{34}$, wcześniej znacznie mniej powszechny. Formy angielskich naczyń ceramicznych odnotowanych w gdańskich materiałach, łączą dwie istotne cechy, które we wcześniejszych okresach w dużej mierze zależały od zamożności użytkowników ${ }^{35}$ - estetykę i jednocześnie standaryzację produkcji poszukiwanych kształtów ${ }^{36}$, która obniżała cenę. Były to elementy zapewniające powodzenie tych naczyń, skutecznie zastępujących wyroby holenderskie na gdańskim rynku. Ich stopniowy zanik, prawdopodobnie w 2. ćwierci XIX wieku, wynikał z kolei z większej konkurencyjności pruskich wyrobów fajansowych i porcelanowych. Być może estetycznie odbiegały one od angielskich, ale produkowane już w pełni maszynowo, w ośrodkach zlokalizowanych znacznie bliżej, były atrakcyjne ze względu na cenę. W Gdańsku pruskie produkty wyparły asortyment naczyń angielskich prawdopodobnie pod koniec XIX wieku. W wynikach analizy materiałów z Gdańska zwraca uwagę znaczący udział procentowy wyrobów angielskich w ostatniej ćwierci XVIII i początkach XIX wieku wskazując na ich obecność w obrocie detalicznym, a więc dostępność rynkową. Niestety, w archiwaliach, szczególnie zaś w księgach palowych i rejestrach portowych nie ma informacji o dużych ładunkach tej kategorii produktów. Prawdopodobnie wyroby tej kategorii docierały do Gdańska w niewielkich ilościach, jednak często, nie podlegając ocleniu. Taką możliwość stwarzały angielskie węglowce regularnie odwiedzające gdański port.

Obecność w Gdańsku kolejnej grupy angielskich wyrobów ceramicznych - fajek jednorodnych - była kontynuacją wcześniejszej mody. Wyroby o takiej proweniencji znano w nadbałtyckim porcie już od końca XVI wieku. Analizowane materiały wskazują, że brytyjskie produkty stały się powszechniejsze (liczniejsze w analizowanym przedziale chronologicznym) w 2. połowie XVIII wieku, a ściślej, podobnie jak naczynia ceramiczne, w okresie od lat 70. XVIII do początku XIX wieku. Poza fajkami londyńskimi, w Gdańsku obecne były wyroby z Liverpoolu i Glasgow. Dalszych badań wymaga ustalenie liczby londyńskich egzemplarzy. Przeprowadzone badania wskazują, że w XVIII wieku mogły one stanowić produkt dostępny w sprzedaży detalicznej. Inne wnioski nasuwają się w odniesieniu do wyrobów z Liverpoolu i Glasgow. Duża różnorodność form i wytwórni fajek nie wskazują, aby produkty tej kategorii, poza niewielkim, „prywatnym” obiegiem rynkowym były szerzej dostępne w Gdańsku.

\footnotetext{
${ }^{34}$ Każda potrawa podawana w jednym dużym naczyniu, tak aby można nabrać właściwą porcję.

${ }^{35} \mathrm{~W}$ obrębie grup średniozamożnych i bogatych.

36 Zestawów do picia kawy czy herbaty lub zastawy stołowej.
} 
Nieco odmienna sytuacja ma miejsce w odniesieniu do ceramiki budowlanej. Obecność cegieł ogniotrwałych z sygnaturami wytwórni angielskich oraz elementów systemów wodociągowo-kanalizacyjnych, ze względu na inżynieryjne przeznaczenie, nie jest przypadkowa. Cegły angielskie przybywały do Gdańska podobnie jak holenderskie na statkach, jako balast. Informacje na ten temat pochodzą z rejestrów komory palowej w Gdańsku, gdzie wymieniane są brytyjskie jednostki handlowe oraz węglowce przypływające do portu pod balastem, a wypływające załadowane. Prawdopodobnie, aby zwiększyć zyski, statki pod balastem dostarczały do Gdańska niewiele angielskich wyrobów różnej kategorii, sam balast w postaci ceramiki budowlanej, niepodlegający cłom, również sprzedawano. Jednak w odniesieniu do elementów konstrukcji systemów wodnych nie ma informacji w opisie ładunków. Można jedynie domniemywać, że tego typu asortyment przybywał do Gdańska na specjalne i wyraźne zamówienia. Jego znikoma, w skali ładowności statku, liczba również nie podlegała rejestracji celnej, zatem prawdopodobnie nie były to wyroby drogie. Warto zwrócić uwagę, że podczas badań archeologicznych rury kamionkowe, ich połączenia i oznaczenia często nie są szczegółowo dokumentowane, co w znacznym stopniu utrudnia określenie skali występowania tej kategorii wyrobów.

Wśród prezentowanych materiałów wskazano trzy główne obszary wytwórczości: rejon Staffordshire i Liverpool, Londyn i okolice, a także Glasgow i Edynburg w Szkocji. Kontakty handlowe Gdańska z wymienionymi obszarami poświadczone są w księgach palowych, a także w tabelach cła sundzkiego. W końcu XVIII i na początku XIX wieku handel Gdańska z Anglią wynosił około 20\%. Wyroby ceramiczne nie stanowiły jego głównej części, jednak ich obecność wskazuje na intensywną wymianą towarów we wskazanych okresach. Największy wzrost oraz zmniejszenie intensywności handlu koresponduje z obecnością głównych grup produktów w Gdańsku. Często przyjmowana przez badaczy ostrożność i opóźnianie występowania określonych „obcych” zjawisk w tym mieście nie znajduje zatem uzasadnienia. Wyroby ceramiczne, szczególnie te dekorowane, są bardzo czułe na modę i percepcję użytkowników, dlatego w świetle intensywnych kontaktów z Wielką Brytanią w omawianym okresie recypowanie produktów „przestarzałych” byłoby niecelowe.

Niniejszy artykuł stanowi wprowadzenie do zagadnień związanych z obecnością brytyjskich wyrobów ceramicznych w Gdańsku oraz z kontaktami handlowymi obu regionów; jest to pierwsza taka próba podjęta z perspektywy archeologicznej. Niewątpliwie będzie ona wymagała uzupełnienia (między innymi w zakresie zagadnień dotyczących asortymentu wspomnianych wyrobów), jednak może być inspirująca do poszukiwania i charakterystyki źródeł pozyskiwanych w efekcie badań archeologicznych. Przedstawiona pierwsza odsłona tego bardzo złożonego zagadnienia stanowi asumpt do dalszych szczegółowych studiów. 


\section{Literatura}

Atkinson D. L., Oswald A.

1969 London clay tobacco pipes, Oxford, England.

Barker D.

1986 North Staffordshire post-medieval ceramics: a type series. Part 2: Blackware, Staffordshire Archaeological Studies, New Series, 3, s. 58-75.

1990 William Greatbatch: a Staffordshire potter, London.

Bartels M.

1999 Steden in scherven. Vondsten uit beerputten in Deventer, Dordrecht, Nijmegen en Tiel (1250-1900), Zwolle-Amersfoort.

Brooks A.

1997 Beyond the fringe: transfer-printed ceramics and the internationalisation of Celtic myth, International Journal of Historical Archaeology 1(1), s. 39-55.

1999 Building Jerusalem: transfer-printed finewares and the creation of British identity, [w:] Familiar past? Archaeologies of later historical Britain, red. S. Tarlow, S. West, London, s. 51-65.

2005 An archaeological guide to British ceramics in Australia, 1788-1901, Australasian Society for Historical Archaeology, Sydney and La Trobe University Archaeology Program, Melbourne.

2010 A not so useless beauty-economy, status, function, and meaning in the interpretation of transfer-printed tablewares, [w:] Table settings: the material culture and social context of dining, AD 1700-1900, red. J. Symonds, Oxford, s. 154-162.

Brooks A., Rodríguez A. C. Y.

2012 A Venezuelan household clearance assemblage of $19^{\text {th }}$-century British ceramics in international perspective, Post-Medieval Archaeology, t. 46(1), s. $70-88$.

Cegła $w$ architekturze

2002 Cegła w architekturze środkowo-wschodniej Europy. Historia-metody badań - konserwacja, red. M. Arszyński, M. Mierzwiński, Malbork.

Copeland R.

2009

Dąbal J.

2008 Asortyment naczyń ceramicznych, [w:] Wrak statku General Carleton, 1785, t. 1: Badania archeologiczne Centralnego Muzeum Morskiego w Gdańsku, red. W. Ossowski, Gdańsk, s. 223-234.

2009 Relikty nowożytnej zabudowy murowanej odsłoniętej w efekcie prac archeologicznych przy ulicy Jaglanej 3/5 (SAZ 0255/20/46). Badania 2006-2008, maszynopis w archiwum Muzeum Archeologicznego w Gdańsku, Gdańsk.

2012 Relikty nowożytnej zabudowy murowanej odsłonięte w efekcie prac archeologicznych przy ulicy Podwale Przedmiejskie 519/7 w Gdańsku 
(SAZ 0255/029/06). (Badania sierpień 2011 - styczeń 2012), maszynopis w archiwum Pomorskiego Wojewódzkiego Konserwatora Zabytków w Gdańsku, Gdańsk.

Draper J.

2001 Post-Medieval pottery 1650-1800, Shire.

Dyba A.

2009 Stan i potrzeby badań nad nowożytna fajka gliniana $w$ Gdańsku, [w:] Stan badań archeologicznych miast $w$ Polsce, red. H. Paner, M. Fudziński, Z. Borcowski, Gdańsk, s. 417-435.

Edwards D., Hampson R.

2005 White salt-glazed stoneware of British Isles, Suffolk.

Gallagher D. B.

1987a Thomas White tobacco pipe manufacture of Cannongate Edinburgh, [w:] The archaeology of the clay tobacco pipe: X. Scotland, red P. Davey, British Archaeological Reports, British Series, t. 178, Oxford, s. 26-28.

1987b Glasgow, [w:] The archaeology of the clay tobacco pipe: X. Scotland, red. P. Davey, British Archaeological Reports, British Series, t. 178, Oxford, s. 35-164.

Gurcke K.

1987 Bricks and brickmaking: a handbook for historical archaeology, Moscow. Hamilton J. F. A., Lunn K.

1984 Three centuries of clay tobacco pipes from London, England, Research Bulletin, nr 227, Parks.

Higgins D.

2009 England, Journal oft he Academie Internationale de la Pipe, t. 2, s. 41-50.

2010a Clay tobacco pipes from excavation at Liverpool Canal Link Site, 2007, maszynopis w The National Pipe Archive Liverpool, Liverpool.

2010b Clay tobacco pipes from the Williamson Tunnels, Liverpool (SJ 363 901), Society for Clay Pipe Research Newsletter 78, s. 41-51.

Hildyard R.

1999 European ceramics, Philadelphia.

Jewitt L. F. W.

1865 The Wedgwoods: being a life of Josiah Wedgwood, with memoirs of the Wedgwood and other families and a history of the early potteries of Staffordshire, London.

Kilarska E., Litwin J.

1985 „English Delftware” z przedstawieniami statków gdańskich, Gdańskie Studia Muzealne 4, s. 89-101.

Kubalska-Sulkiewicz K.

2003 Stownik terminologiczny sztuk pięknych, Warszawa.

Lawley I.

2010 The potteries, Gloucestershire. 
Lucas G.

2003 Reading pottery: literature and transfer-printed pottery in the early nineteenth century, International Journal of Historical Archaeology, t. 7, nr 2, s. 127-143.

McIntyre-Brown A.

2002 Liverpool, the first 1000 years, Liverpool.

Mikłaszewicz D.

1994 Fajki z badań archeologicznych $w$ Toruniu, Pomorania Antiqua, t.16, s. 329356.

Miller J. J., Stone L. M.

1970 Eighteenth-century ceramics from fort Michilimackinac. A study in historical archaeology, Washington D.C.

Oniszczuk-Rakowska A.

2002 Ceramika nowożytna z latryn posesji przy ulicy Szklary 2-5 w Gdańsku, [w:] Dominikańskie Centrum św. Jacka w Gdańsku. Badania archeologiczne, t. 2, red. A. Gołembnik, Światowit, Supplement Series P: Prehistory and Middle Ages, t. 9, s. 207-272.

Oswald A.

1975 Clay pipes for archaeologist, British Archaeological Reports, British Series, t. 14, Oxford.

Prentice R.

1994 A celebration of the sea. The decorative art collections of the National Maritime Museum, Greenwitch.

Rickard J.

2006 Mocha and related dipped wares 1770-1939, Lebanon, New Hampshire.

Rutherford D.

1996 Classical economics: the critical reviews, 1802-1852, t. 1, London.

Samford P. M.

1997 Response to a market: dating english underglaze transfer-printed wares, Historical Archaeology 31(2), s. 1-30.

Shaw S.

1829 History of the Staffordshire potteries and the rise and progress of the manu-

Skowrońska E. facture of pottery and porcelain, Hanley.

2011 Ceramika budowlana z kompleksu klasztornego augustianów-eremitów w Stargardzie. Wprowadzenie do badań nad detalem, Stargardia, t. 6, s. $133-145$.

Sussman L.

1977 Changes in pearlware dinnerware, 1780-1830, Historical Archaeology 11, s. $105-112$.

Szelegejd B.

2007 Ceramika europejska, Warszawa. 
Tatman C.

1994 The clay tobacco pipe industry in the Parish of Newington, Southwark, London, [w:] The Archaeology of the Clay Tobacco Pipe XIII, red. P. Davey, British Archaeological Reports, British Series, t. 239, Oxford.

The archaeology

1987 The archaeology of the clay tobacco pipe: X. Scotland, red. P. Davey, British Archaeological Reports, British Series, t. 178, Oxford.

Thijssen J. R.

1993 Engelse indutriële keramiek, [w:] Schans op de grens, red. J. Lenting, H. Towner D.

1978 Creamware, London.

Walker I. C.

1971 Some notes on the Westminster and London tobacco-pipe makers' guild, London and Middlese $\times$ Archaeological Society Transaction, t. 23, cz. 1, s. $78-98$.

\section{BRITISH CERAMICS IN GDAŃSK LOCAL MARKET IN $18^{T H}$ AND $19^{T H}$ CENTURY}

Summary

Problems taken up in the article concern English and Scottish ceramics from the periods starting with $18^{\text {th }}$ up to $19^{\text {th }}$ century, obtained in the course of archaeological explorations in Gdańsk (sites within the area of the Old Town, Old Suburbs, Southern Granary Island and Szafarnia). Author presented ceramic assemblages consisting of, among the others, ceramic vessels, pipes and ceramic building material. Due to a wide range of the research performed and rich source base of this work, initially - the characteristics of particular objects' categories were presented. Further, chronology and informative potential, resulting from their occurrence in Gdańsk local market, were defined.

The vessels consisted of stoneware, creamware, blackware and redware. They were subjected to analyses in reference to their manufacturing techniques and the way of decorating. Another products' group consists of clay tobacco pipes, which were characterized taking into account production centers. Examples from London, Liverpool and Scotland were distinguished. The last discussed group consisted of brick and stoneware water-pipes - elements of water-sewage systems. On the base of marks: Ramsey and Prestongrange, main centers of their productions were identified.

Preliminary analysis of the objects listed indicates some general regularities connected with their functioning in Gdańsk. The biggest number concentration of pipes and ceramic dishes of English origin is noted for the period of the 80 s of $18^{\text {th }}$ century up till the end of that century. In case of ceramic building material the most artifacts come from the end of $19^{\text {th }}$ century. Ceramic objects come in majority from Staffordshire and Liverpool region. Building ceramics and single clay tobaco pipes come from the eastern coasts of Great Britain. Quantity and specificity of particular objects' categories indicate 
that ceramic vessels and elements of water insulation must have been imported to Gdańsk on a mass scale.

Present article is barely an introduction for the futher researches of British ceramics in Gdańsk and their trade between these two regions. Issues concerning the products assortment presented above require further studies. 